

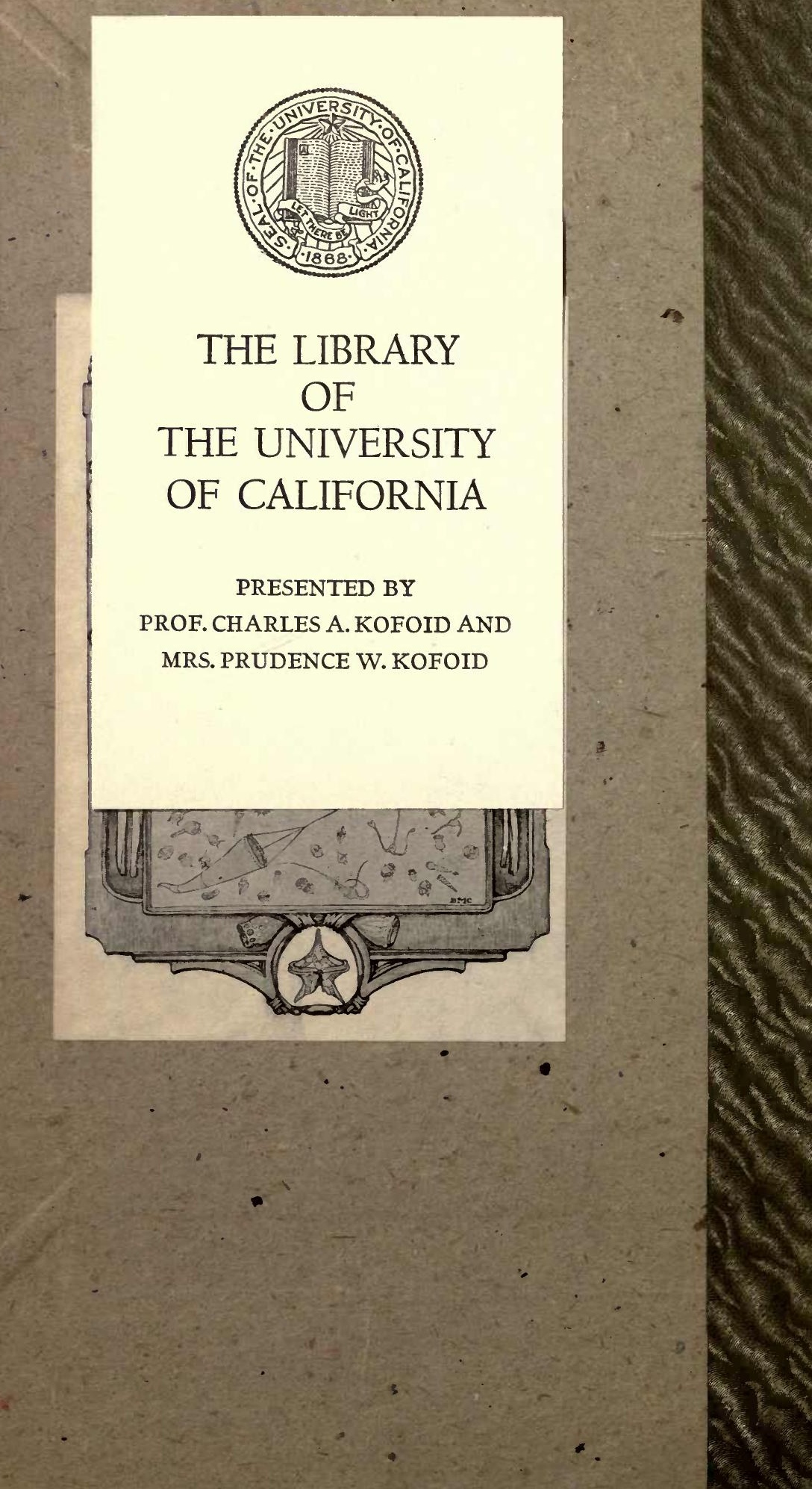




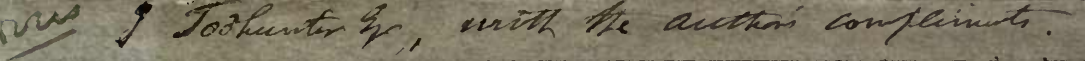

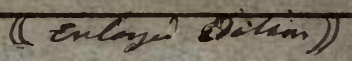

. Which Strain at a Gnat and Swallow a Camel."

"Origin of SPECIEs."-Darwin.

ALL THE

ARTICLES

OF THE

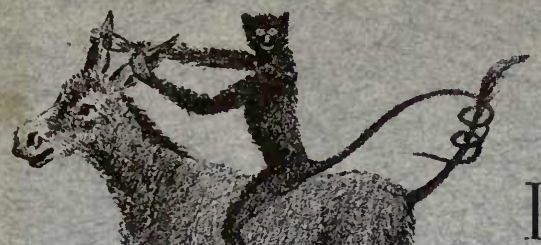

DARWIN

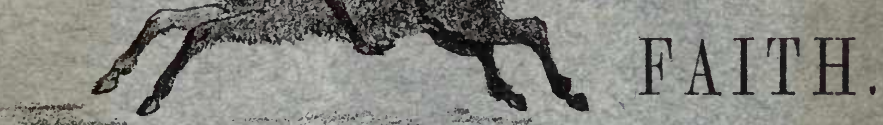

QUADRUPED.

BY THE REV.

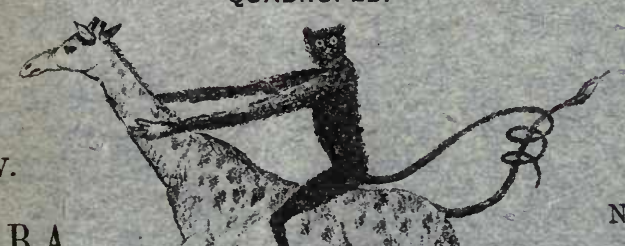

Rector of

F. 0. MORRIS, B.A.,

Author of

A History of British Birds," dedicated by permission

"Ridiculum acri fortius ac melius

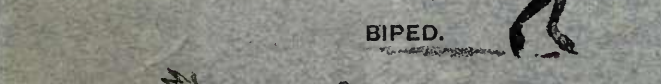

to her most gracious

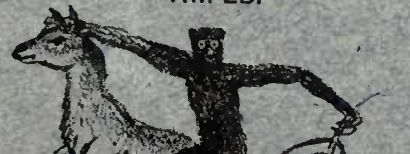
Majesty the Queen, etc., etc.

plerumque secat res."

HORACE.

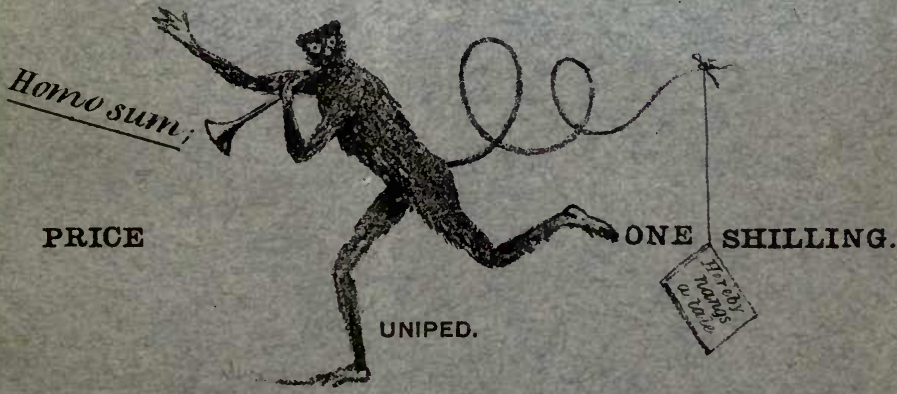

"Diffrenentiated into Max."-Tyndall.

REDOUBLED Edition.

LONDON: WILLIAM POOLE, 12, PATERNOSTER ROW, E.C. 1877. 
D E D I C A T E D

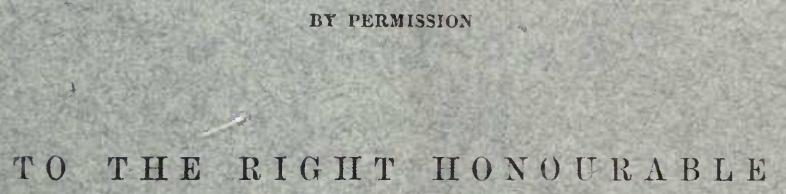

THE COMMON SENSE

or

THE PEOPLE OH ENGLAND. 
P R E F A E.

$$
\begin{gathered}
K-4 H 369 \\
M 58 \\
18.77 \\
\text { Bio } \\
4.5
\end{gathered}
$$

I Have much pleasuro in giving the following Pentaree and Coat of Aris of tile Darivinian Family.

The antiquity of this very ancient race is beyond dispute, its genealogy having been furnishel by the present head of the family himself, so that its authenticity and its genuineness are both alike established.

It traces its origin to an ancestor who lived, or vegetated, it is not quite certain which, billions upon billions of years before the "year one" of our records. It is briefly given, as above stated, on pages 10 and 11 of the present work, from which it is clearly shown that neither families of Norman, or Sazon, or even, betore them, of Ancient British origin, are fit to be named in the same day with it for precedence.

It is also extremely interesting to notice that a coat of arms was borne by the first man-so, though not quite correctly, strictly speaking, to call him-thongh it appears that he wore no other clothes of any kind.

Of still more importance is it to note that all the doubts which have heretofore existed as to the origin of language, are hereby and for ever set at rest.

For though it is, indeed, true that in our times mottoes may be changed at pleasure, while shields and erests can not, yet it need not for a moment be supposed that such was the case in that early period whereunto no record or "memory of man runneth."

Hence, "I believe," "we may believe," "I cannot doubt," "I can incleed hardly doubt," by the "use of Imagination," or, in other words, it is certain, that both Latin and English were, in common parlance, the speech of the great ancestor of the Darwinian race.

Buzon of tire Coat of Arms of the Darwinian Fanily:

Party per pale, quarterly, first and fourth, azure ("the infinite azure of the past"), a demi-semi-savage, sable, standing on vacaucy, decorated with the Order of the Garter on the right knee, and with a long tail curled up; over it a scroll with the legend, "I could a tale unfold," and the motto, "Non tali auxilio." Second and third, a mermaid, vert, in full ball costume, crined, hair dressed a la Eugenie, and wreathed with an embroidered sash or girdle marked with the words, "Desinit in piscem mulier formosa superne."

On an escutcheon of pretence, per bend, gules and argent, interchanged, a Philosopher, in Puris Naturalibus Selectissimis, standing on the air, in nubibus, gorged with a bar sinister, and holding in both his hands a library of lectures, intituled, "De omnibus rebus et quibusd tm aliis."

Crest, a monkey rising out of a monad, all improper, within a halo of mocnshine.

Supporters, dexter, a bear naiant, argent, tusked and langued, "witl lirs mouth open catching flies" (Darwin), "very like a whale" (ditto). Sinister, a giraffe, rampant reguardant, gules, the tail nowhere, but in place of it the legend, Non est inventus, and over the head a swarn of Tzetze flies.

Mottoes: Above the arms, Qui vult decipi decipiatur; beneath the arms, Sic volo, stet pro ratione voluntıs ; under the crest, "Homo sum ;" above the crest, "Am I not a man and a brother?"

With these few prefatory remarks I leave the following "Confession of Frith" of the present representative of the "Origin" of mankind, to commend itself, as best it may, to the common sense of the people of England, well assured and confident that they will thoroughly appreciate the great value of Darwinism to immortal men. 
"The old questions whence men come and whither they go, and what is the end of all their labour, still perplex philosophers and trouble the simple. The anxieties of the human soul force their way even through French logic into the midst of the Positive Philosophy. As long as such questions are asked, so long will there be an ear for an answer."

Trmes, Octoher, 1869.

.. The highest intellect which issues in no certainty has completely failed."-Thomas Carlyle, 1869.

"Every few years some reformer or another has sprung up . . . . and all past as well as all present experience further shows, that the greater the degree of dogmatism and effrontery with which any such pretender proclaims his doctrine, the greater in all probability will be his success in gaining patrons amongst the credulous public."

Sir J. Y. Simpson, BaRT., M.D. 
"O ye fools, when will ye understand?..... He that made the

EYE; shall He not see!"-Psalm xciv. 8, 9.

\title{
ALL THE
}

\section{ARTICLES OF 'THE DARWIN FAIT'H.}

\author{
Credo Quia Impossibile Est.
}

BELIEVE that we are the people, aud that wisdom shall die with us.

I believe, I am ready to believe, anything-like the Infidel of oldprovided only it is not in the Bible.

I believe that my theory of natural selection is right, and that every one who does not hold it is in the wrong, although the difficulties "are so grave, that to this day I can never reflect on them without being staggered." (Darmin.)

I believe that man, and all the animals, birds, fishes, reptiles, and insects in the world have descended from one single original, and not any of these from ancestors of their own kinds; that the gnat and tie elephant, the cat and the mouse, the bat and the butterfly, the whale and the ant. the toad and the swallow, the hare and the tortoise, the crocolile and the lamb, the humming-bird and the snake, the mole and the monkey, and then the man, are all one species-and only one.

I believe this, although I see that while animals of the several species described by naturalists breed solely together, and that their offspring are prolific, in like manner, generation after generation, any others which may exceptionally breel together have no progeny, except in very rare cases, and that any they may have leave no descendants, except still more rarely for perhaps one further generation or so.

I believe that ali the various creatures on the earth have sprung from a single parent, althcugh I hold that each new species has "supplanted and exterminated its original parent and all the trunsitiomal varictics between its past and present status." (Darmin.)

I believe that the drooping of the ears in domestic animals is due to the disuse of the muscles of the ear, from the animals not being much alarmed by danger, althou,h I see the horse with erect ears, and the hare and the rabbit with strikingly diooping ears.

I believe that the temporary variation of several races of any one species of plast is a proof that permanent so-called species are thus produced, although I see that the varieties if left for many generations in a poor soil would to a large extent by degrees, and in the end wholly, revert to the form of the wild aboriginal stock.

I believe that I am using an able and sensible argument in saying that the mistletoe may metaphorically be said to struggle with other fruit-bearing plants in order to tempt birds to devour and thus disseminate its seeds rather than those of other plants. 
I believe that the eye of every living creature was produced by natural selection, although in some species it consists of 4,000 lenses, in others $12,000,17,000$, or 25,000 , and in others of various other vast numbers.

I believe that my theory is right, although I allow that according to it "all nature" ought to be "in confusion" instead of the species being, as we see them, "well defined." (Darnin.)

I believe- "there seems to me no great difficulty in believing"(Damin)-that the swim-bladder in fishes "though originally constructed for one purpose," has been "actually converted" "into a lung or organ used exclusively for respiration."

I believe that the "electric organs of fishes" have been produced by " natural selection," although it is "impossible to conceive by what steps those wondrous organs have been produced." I believe this, although these organs only occur in species "widely remote in their affinities," while we "might hare expected" (on Darwinian grounds), that they would all "have been specifically relater to each other." I believe the same in the like cases of luminous insects.

I believe that the most simple parts of species are due to natural selection, although I see that their "importance does not seem sufficient to cause the preservation of successively varying individuals."

I believe that the tail of the giraffe has grown by degrees into a "fly-flapper" (!), although I cannot explain how the species did without it in previous countless ages before it grew to its present length, when, no doubt, there were just as many flies in those hot countries, if not more, than there are now.

I.believe that every "well-developed tail" in a water animal has been "worked in " as a "fly-flapper" for land animals, or as a "prehensile instrument," or to " help them in turning ;" although I see that in the $\operatorname{dog}$ it is of next to no such use at all, and that the hare can double quickly enough, though with hardly any tail.

I believe that long tails are necessary to animals in hot countries to give them the "power of resisting the attacks of insects," although I see that sheep have heavy tails which they cannot and do not make use of for any such purpose, and are especially attacked by flies on their heads, which, if their tails were ever so light they could not possibly reach.

I believe that-as I hold that the swim-bladder in creatures of the sea is modified into lungs in their descendants changed into land animals - the tail, having been so useful to the former as a means of locoinotion, still proves its origin in the latter, though of so little use to them.

I believe that the green colour of the green woodpecker is due to selection by the male or female bird, because I see that there are black and pied woodpeckers also.

I believe that it is not the case that many structures have been created for beauty in the eyes of man, or for mere variety, although I "fully admit that many structures are of no direct use to their possessors."

I believe that there is "no logical impossibility in the acquirement of any conceivable degree of perfection through natural selection," although I must admit that the case of the eye is "more than enough to stagger any man."

I believe that the American ostrich "is not yet perfect," although I can give no proof whatever that it is in the process of becoming so.

I believe that the "most wonderful of all known instincts," that of the hive bee, can be explained by me, as a Darwinite, and the 
illogical way in which it has been attempted to be accounted for in the work on "The Origin of Species" I believe to be a master-piece of reasoning, though nine out of ten of its facts prove nothing whatever by way of conclusion for it.

I believe the same in the case of the working or sterile ants, though "how the workers have been made sterile is a difficulty ;" that is to say, in itself, but none whatever to my more "fertile" brain, which thinks nothing of any difficulty that stands in its way.

I believe that the difficulty, though " appearing insuperable," "disappears" by my imagining that selection may be exercised by a whole "family" as well as by an "individual." I choose to forget that families are made up of individuals.

I believe that on my theory no account need be taken of the "prodigious amount of difference. between the fertile and sterile individuals of many insects."

I believe that my theory is perfectly correct, although there is a "climax of the difficulty" beyond all these that I have yet stated, some of the neuters differing even from each other to an "almost incredible degree ;" some "with jaws and instincts extraordinarily different;" others with forms "the use of which is quite unknown."

I believe that I am right, and all the world else wrong, although it will be thought that I have an "overweening confidence in my own wisdom," which makes me " not admit that such wonderful and wellestablished facts at once annihilate my theory."

I believe that I must be right, although I can't "pretend that the facts given in this chapter (VII.) strengthen in any degree my theory," and that all I can say is that they do not "annihilate it;" ergo I must be right.

I believe that the sterility of hybrids is no disproof of my theory of natural selection, which is that it acts for the good of the creatures which exercise it, although it could not possibly be of any advantage to the several animals, and although I think that the importance of the fact has been "much underrated by some writers."

I believe that my theory of hybridism is right, although it does not "go to the root of the matter" and "no explanation is offered" of the main fact. "Ibrida quo pacto sit" is quite beyond me.

I believe that "no part of the structure of any one species has been formed for the exclusive good of another species, though " natural selection" can and does often produce structures for the direct injury of other species, and though I see that the aphis voluntarily uses its structure for the sole good of the ants, and I can only "probably" imagine that it is of any convenience to the aphides themselves.

I believe that tumbler-pigeons have been produced by the long continued selection of such in many generations, though I can't at all tell how they first came to have the habit, or why it should have been fortunately noticed by some fancier, or how he came to think that it might be propagated and preserved, and succeeded in doing so.

I believe that I strengthen my argument by saying that dogs only rarely require, when young, to be taught not to attack sheep, etc., though I see that it is the very commonest thing that some dogs can never be broken of the habit, and that there is not a dog in existence but might be encouraged to it.

I believe generally that "natural instincts are lost under domestication," although I have the preceding fact and numberless others staring me in the face to show me the exact contrary, and that they are at the most but dormant, and ready to be restored to their former fulness.

I believe that young chickens have lost by habit the fear of dogs 
and cats, although I have no possible proof whatever, and cannot pos. sibly have any proof, that they ever had such.

I believe that the cnckoo "once upon a time" did not lay her eggs in other birds' nests, but has acquired the habit by degrees, some "old bird" or other profiting by the mistake, or the young being made stronger by it, viz. : by being tended by a foster parent instead of by their natural one! and so becoming " apt to follow" that unnatural practice; and this though I see that various birds "occasionally " lay their eggs in other birds' nests, and yet have acquired no such habit.

I believe that although in spite of an "enormous accumulation of prolubilities, we yet stand without the direct production of a new species from one common stock," yet nevertheless, against the evidence of my senses, I believe, I say, that such has been the case with all the so-called species in the world.

I believe that although the remains of the horse existed in geological strata of "enormous antiquity" long before any indications of the existence of man have yet been found,-and although those remains show that the horse and the ass at that remote period exactly resembled in nearly every respect the horse and the ass which now run wild in many parts of Asia and Africa,-and although, "going still farther back to the Upper Miocene period, the horse is still found with its present peculiarities, and the two differ from each cther only in minute details," - yet as the remains of the hipparion or "little horse," are found in the same deposit as the horse, namely, the Upper Miocene, so that it could not have been its ancestor, though like it in several respects, and as the remains of the anchotherium are only found in the Lower Miocene, so that there is a wider gap between it and the hipparion than between the latter and the horse, still, for all that, inasmuch as in the anchotherium the leg bones are still more separated, as it has three bones on the fore limb, which "theory requires that it should have," (!) " it being impossible to obtain evidence more complete in kind than this of the origin of the horse," ergo, I say, I believe that the horse is descended from the anchotherium.- $\mathbf{Q}$. E. D. (Huxley.)

Horses have sometimes been born with extra toes, ergo I believe that "the horse must at one time have had the leg and foot bones complete, although they were blotted ont before the horse was turned into a perfect running machine!" (Hu.rley.)

The Darwin Doctrine thereiore being THus (!) " made out in this one case of the horse," I believe that it is strong evidence that "similar modifications have taken place in all cases." (Huxley) (Equally strong, no doubt! No doubt at all about it !)

I believe that the common saying that one "cannot draw blood out of a stone" is the reverse of truth, and that not only bones, sinews, and life can be produced from them, but also, mind, reason, and the roice of conscience, - which though would-be philosophers and atheists brave out in daylight, they are so horribly afraid of in the dark.

I believe that I alone am right, although I see that though slight crosses benefit the offspring, greater crosses, i.e., those of widely separated species, produce sterile hybrids, and I "cannot persuade myself that this parallelism (!) is an accident or an illusion."

I believe I am right, although I see that the widely different forms of the pigeon among birds, and the cabbage and other varieties among plants, are productive together, while other species "though resembling each other most closely, are utterly sterile when crossed," and I admit that the former is "almost invariably the case."

I believe that the "imperfection of the geological record," showing no regular chain of species, and so giving no proof of my theory, and 
therefore the most obvious and gravest objection that oan be urged against it, may nevertheless be assumed by me as conclusively proving it.

I believe that it is a sufficient answer to the question what has become of the innumerable forms which must have existed before the Silurian deposit, that "long before that" the world "may have," then, "presented a totally different aspect;" that the older continents, "may" now "all be in a metamorphosed condition," or " may" "lie buried under the ocean;" that there has "probably" been more extinction of species during the periods of subsidence, and that the duration of each formation was "perhaps" short compared with the average duration of specific forms.

In fine, I believe that although the Mosaic account of the Creation is borne out by the "Testimony of the Rocks" in a most wonderful manner, yet as it does not suit the theory I have taken into my head, it cannot possibly be true, and I do not believe a word of it.

I believe that if ever there was such a person as Moses, the five books called the five books of Moses were none of his at all, but a mere compilation of some impostor or victim of delusion.

I believe that no one who believes in the Bible has any sense or wisdom compared with me, in accounting for the Creation of the world and all the creatures in it.

I believe that such persons in former times as Sir Isaac Newton, Herschell, Lord Bacon, Dr. Johnson, Milton, Locke, Sir Matthew Hale, etc., etc., etc., who were Believers in the Bible, must have been utterly wrong and mistaken, and in the dark as to such matters.

I believe, in like manner, that others in the present time who are Believers also, as they were, such as Sir Roundell Palmer (Lord Selborne), Lord Hatherley, Lord Shaftesbury, Faraday, Sir David Brewster, etc., etc., etc., and others who like them have taken the highest honours in the Universities, and distinguished themselves in the highest departments of art, science, and politics, are also quite in the dark, for if I am right, as I must be, and therefore am, they of course must be wrong.

I believe that mine is a much more valuable opinion, and much more to be received than that of Humboldt, who said of Strauss "what displeases me in him is the scientific levity which causes him to see no difficulty in the organic springing from the inorganic, nay, man himself, from the Chaldæan mud."

I believe that the following supposititious guesses are "worthy of all men to be received," and should be accepted by all the world as scientific facts and truths, inasmuch as "I have spoken ;" namely,-

I believe, "By considering the embryological structure of manthe homologies which he presents with the lower animals - the rudiments which he retains-and the reversions to which he is liable,we can partly recall, in imagination, the former condition of our early progenitors, and can approximately place them in their proper position in the zoological series. We thus (!) learn that man is descended from a hairy quadruped, furnished with a tail and pointed ears, prvbably arboreal in its habits, and an inhabitant of the Old World. This creature, if its whole structure had been examined by a naturalist, would have been classed amongst the quadrumana, as surely as would the common and still more ancient progenitor of the Old and New World Monkeys. The quadrumana and all the higher mammals are probably derived from an ancient marsupial animal; and this, through a long line of diversified forms, cither from some reptile-like or some amphibian-like creature, and this again from some fish-like animal. In the dim olscurity of the past we can see (?) that the early progenitor of all the vertebrata must have been (?) an aquatic animal, provided 
with branchix, with the two sexes united in the same individual, and with the most important organs of the body (such as the brain and heart) imperfectly developed. This animal secms to have been more like the larva of our existing marine Ascidians than any other known form." (Quite so!)

I believe that an argument based on that which seems, is quite as valuable as one based on that which is; that a chain with gaps in the links, is quite as firmly held together as one without; and to lack no evidence but that of facts is amply sufficient for me, of which the following will serve for examples.

I believe - "I cannot doubt, that the theory of descent with modification embraces all the members of the same class." "I can indecd hardly donbt that all vertebrate animals having true lungs are descended by ordinary generation from an ancient prototype, of which we know nothing, furnished with a floating apparatus or swim bladder."

I believe-" It is conceivable, that the now utterly lost branchiæ might have been gradually worked in by natural selection for some quite distinct purpose, in the same manner as . . . it is probable that organs which at a very ancient period served for respiration, have been actually converted into organs of flight."

I believe that the opinion of Dr. Carpenter on the non-progressive character of the Foraminifera is as valuable as that of "any other" man in England" (except myself) : and therefore whereas Dr. Carpenter distinctly asserts that there has been "no advance in the Foraminiferous type from the Palaozoic period to the present time," and states his conviction that "the present state of scientific evidence, instead of sanctioning the idea that the primitive descendants of the type or types of Foraminifera can ever rise to any higher grade, justifies the antiDarwinian inference, that however widely they diverge from each other and from their origins, they still remain Foraminifera," I believe that as I think differently from him, he must be wrong, and I must be right.-Q.E.D.

I believe that an assertion "not proven" is as good as, or better than, one that is proved.

I believe that I must admit Dr. Carpenter's. assertion as an "absolute matter of fact;" but for all that, as it does not suit my theory, I must hold that "as we do not know under what forms, or how, life originated in this world, it would be rash to assert that even such lowly endowed animals as the Foraminifera, with their beautiful shells, as figured by Dr. Carpenter, have not in any degree advanced in organization!"

I believe, therefore, that we can thus "partly recall" the former condition of our earlier progenitors ; though even that "partly" is in imagination!" Thus! too, we can "approximately place them in their proper position" (" in imagination"). "We thus learn," also " in imagination," about the "tail and pointed ears," "probably derived" from something-or from something clse (" some reptile-like, or some amphibianlike creature") or "this again from some fish-like animal." Thus " in the dim obscurity of the past, we can see" (?) what this animal "must have been ;" or what I must after all own it to have been.

I believe this is a highly satisfactory and conclusive result of the "eleven years" labour I have expended on my last publication.

I believe that all the wisest men in the world for the six thousand years since it is commonly supposed to have been created, or six hundred thousand million years, or any number more, as I believe, have been altogether wrong, and that it has been reserved for me in this so-called nineteenth century to set them all right and lay down the law for ever. 
I believe that it may help my argument, if I can find people simple enough to believe that humble bees are common in gardens, and scarce elsewhere in comparison, in consequence of their being preyed on by field-mice which are kept down by cats about houses; the fact being, as any national-school boy can see, that these bees abound near woods, or in any other uncultivated places where thistles and other wild flowers which bees are fond of are found, a hundred-fold more than they do in gardens, and that if they are found more or less numerously in gardens, it is only because of there being more flowers there, for which they will fly for long distances, it is said for miles, there being no more nests there than anywhere else, and in ninety-nine cases out of one hundred nothing like so many.

I believe that all creation is derived from some one form, a mere monad, although I admit that "no one can at present say by what line of descent the three higher and related classes, namely, mammals, birds, reptiles, were derived from either of the two lower vertebrate classes, namely, amphibians and fishes."

I believe that it requires several generations of cultivated talent to make the mind equal to higher intellectual attainments, but I find it convenient to forget that it is just as easy a supposition that the debasement of the intellect at any given time, even assuming it as thus to be slowly recovered from, may have been acquired gradually by neglect from a previous height equal to that to be finally attained to.

I believe that there is no such art as logic, at least, if there is, that it is quite beneath me to be guided by it, and that one premiss, or at all events a number of single premisses strung together so as to give a great appearance of argument to those who know no better, is amply sufficient to prove any conclusion.

I believe that the Christian is the happiest of men, because he evidently has a hope for another world in addition to the peaceful happiness he enjoys here.

I believe that an infidel or an Unbeliever is "of all men most miserable ;" nevertheless I have done all I could to make others as wretched as I am myself, and have given, and can give them, nothing in return but a dreary blank. If you ask me about the future, there, I confess, I am in the dark; all I can say is that you and I will "melt into the infinite azure of the past," (Tyndall) (whatever that may mean). I repeat that I believe that Christian Believers have a peace of mind which I have not myself. They have "a good hope" for the future, which I must admit I have not myself, "having no hope, and without GoD in the world." I do my little best, or worst, to shake their faith or rob them of their peace of mind, but I have nothing better, because I have nothing at all to give them in the place of it. I cannot offer them any happiness in this world or in any future state, because I do not believe that there will be any future state, so that if you ask me what is the cui bono of all I have written, I cannot tell you. If you ask me what is the cui malo? that is quite another question, and much more easily answered. I offer you no happiness here or hereafter, and all I can do is to rob those of you who are fond and foolish enough to take up with the idle conceits of my "vain philosophy," of their present hope, and therewith of their expectation of future happiness, which but for me they might have.

I, (Huxley) believe that there is a good deal to be said for the hypothesis, that animals are mere machines, as much so as if they were mills or steam engines, and that they have no feeling; that they do not hear, see, or smell, and that their "apparent states of consciousness," as they seem to us, are only the results of a "mechanical reflex process." ("Risum tencatis amici?" This is philosophy! This 
is science !). It is true I believe that I am only an animal, come from one of them myself, and therefore you may argue that I have no feeling, and may ask me to allow myself to be experimented on accordingly for the good of science, but I must beg of you to excuse me. It might interfere rather unpleasantly with my theory, and with the calmness, - or to speak more truly, the cool assurance, not to use a stronger word-which a "Philosopher" ought to exhibit to the public when he lays down the law to them. No one more ready than a Philosopher to cry out even before he is hurt; but he has no feeling for dumb animals: he keeps all he has for himself.*

I believe it would be highly imprudent in me to accept the chal. lenge which was thrown down to me at the meeting of the British Association in 1874 , to meet the challenger face to face before the public and discuss the truth or otherwise of my assertions. On the contrary, though I have the advantage of a good memory, a fluent tongue, and any amount you please of assurance, if you will oblige me by using so mild a term, I altogether shrink from the touchstone of common sense. Theory and assertion are all I have to do with, to which I always make it a rule (a very convenient one) to bend any given number of facts.

I believe that though Professor Salmon has shown that Darwinism is a mere scientific imagination, not a scientific fact, nevertheless the human species is descended from the semi-human, and this again from so low an origin as the larva or caterpillar of some sea animal.

I therefore believe, for all the above satisfactory reasons, that the origin of man is to be derived as follows:-

1. Marine animals, resembling the larvæ of existing Ascidians.

2. Fishes as lowly organised as the Lancelet.

3. Fishes like the Lepidosirens:

* I here add some few of the terms applied to the places, persons, and practices referred to, by many eminent men :-A " Hell," (Sir ARTHU R HELYS) ; "Abominable and atrocious," (LoRd Shaftesbury); "Hellish," (Dr. Kitching); "Atrocious crimes," "Barbarities," "Wickedness," "Worse than the worst Inquisitors, "Dens of torture," "Disgrace to Science," "Never surpassed in impudence," "Pollutors of the minds of School ("hildren," "Ruffians," "Voung reprobates," "Perpetrators" of atrocities," "Spouters of Blasphemy and Infidelity," "Professors of Brutality," "Worse than Heathen persecutors," "Deceivers of the people," "Scientific crimes," "An outrage to the moral sense of every human being who is not as depraved as themselves," "A few brutalized physiologists," "who go whining about the cointry with the importunity of beggars, becalse every right-minded man and woman in the country is not compelled by law to contribute his or her hard earned wages to sipport the perpetration of crimes which they abhor, (DR. W. B. A. ScotT.) "Disgraceful butchery," "devilish," "loathsome," "fiendish," "would disgrace the lowest type of savages," "merciless and unpitying," "demons," "devilry," "wretches," "a depraved instinct," "frightfully horrible," "disgraceful butchery," "devilish torment," "horrible," " abominable devilry," "brutal beyond conception," "useless beyond belief," "all most horrible," "a disgrace to the profession," "brutal deeds," (A LONDON SURGieON, Mr. Waldron Bradley, in the Echo.) "Detestable villanies, protracted butcheries, degrading the operator far lower than the brute on which he exercised his fiendish skill, soiling the hands in blood, and grovelling in torture for hours, aye for days together," (The late LORD CARNARVON.) "Who have made a path over the bodies of writhing animals to seats of most questionable honour," (J.F.B., in The Hour.) "Their practice as various as their theories." "Much in the aspect of school-boys playing with weapons of which they under stand neither the use nor nature," (ROYAL COMMission, "A set of young devils," (Dr. Havghton.) "A new horror," (PROFEsSOR NEwMAN.) "Cruelty in its worst form is the ultimate result of Science." "Cruelty in the garb and pretences of Science." "Now, Science has become the rival of the tortures of the Inquisition, and by increase of learning has learned to torment still more ingeniously." "Ancient Paganism may well put us to shame." "To cut up a living horse, day after day, in order to practise students in dissection, is a crime and abomination hardly less monstrous from his not having an immortal soul." "An inevitable logic would in a couple of generations unteach all tenderness towards human suffering-if such horrors are endured-and carry us back into greater heartlessness than that of the worst barbarians." "A new oppression." "The scientific Torquemadas of the day." "The inseparable companion of the vilest impurities and vices to $w$ hich flesh is heir," (Saturday Revierv.) 
4. Amphibians.

\%. Reptiles.

6. Monotremata.

7. Marsupials.

8. Placental Mammals.

9. Lemuridæ.

10. Simiadæ.

11. Old World Monkeys.

12. Man.

"O most lame and impotent conclusion!"

I, (Tyndall) believe that I can "prolong my intellectual vision backwards, into regions where the unscientific cannot follow," (none but myself and those who think with me are scientific -in my opinion,) "and can discern in matter the promise and potency of every form and quality of life." All who are opposed to me I, (Huxley), pronounce, ex cathedra to be "pigmies in intellect." This is a very easy way of setting down opponents, and especially becoming, I think, in a "scientific man," who calls himself a "professor" of science. when before the annual meeting of a scientific society. (At Belfast, 1874.)

As to "prolonging my vision" forward, there I am in the dark, even on my own confession. I am compelled to acknowledge that a time may be coming when even a "professor" of irreligion and science, "falsely so called," may have to say to religion, "give us of your oil, for our lamps are gone out" into "outer darkness."

I, (Tyndall), also believe that life is a "continuous adjustment of internal relations to external relations," by which process some original tissue "vaguely sensitive all over" has come by degrees to be "differentiated" into man. "( $O$ Sapientia!)" I do not believe with Darwin in a "Primordial form," the origin of all living beings; I cannot tell whence he proposes to derive it, but neither can I tell you whence my original-(very original!) - "tissue" came. (Dostors differ you see.)

All this is science! knowledge!! philosophy!!! very clear, as well as very useful, and very profitable, is it not? as clear as the "Chaldæan mud."

It is really hard to say which of these "Philosophers" talks and writes in the most senseless manner. These are some of their choicest sayings, - "These be thy Gods, O Israel," and "miserable comforters are they all."

I believe that "the difficulty of understanding the absence of various piles of strata" which, on my theory, no doubt were "somerhere!" " is very great." "The case at present must remain inexplicable, and may be truly urged as a valid argument against the views here entertained," Nevertheless, though I thus own that the evidence of nature is against me and that I cannot get over the difficulty, I cannot give up my own opinion, which must be right.

I believe that as my theory must be true, the records of geology are of no account. For "IF my theory be true" (as of course, as I have said, it must be), "during those vast, yet quite unknonn periods of time, the world swarmed with living creatures," but to the question why we find no remains of them, as we do of others, "I can give no satisfactory answèr." But what matters that? The evidence I want is not to be had, but I can do equally well with or without evidence.

I believe that all existing plants and animals "may" have been "developed" from a seed of a seaweed, and if we admit this, as we must, because I fancy it, then there can be no difficulty about the matter. It may have been first "characteristically animal," and then "unequivocably vegetable;" and "I cannot doubt" but that it held within it the potential existences of all creation, so as to develop in 
the end into a whale and a crab, a butterfly and a tortoise, an oak tree and a man. But if you ask me who were its parents, or how it was first made, or how it acquired its double quality of animal and vegetable, you must go to some one else than me for an answer. I decline giving one, for the best of all possible reasons.

I believe that it was. That must be enough for you. What was the "origin" of this "species" I cannot tell you, though all my book pretends to be about it." It went "on the principle of Natural Selection with divergence of character." Is not that clear enough for you? I say that it was so, though how it came by natural selection, when there was nothing to select, is beyond even my capacity to say; nor how the next came from it, nor whether the animal came first or the vegetable. All I can tell you is that there was some "divergence of character " in the first seed, some "modification," some "development," some "plastic" tendency, so that the first seed had to "struggle for existence" with itself, for there were then no others to struggle with; and thus came out of one both male and female, and so on till the process came down to man!

I believe all this. It "does not appear incredible" (to $m c$ ), yet, as to how "the first steps in advance" came "out of the original simplest structure, I can make no sufficient answer," and can only say that "all speculation on the subject would be baseless and useless." So that though I own that here we have no facts to guide us, still, as I say it is "not incredible," what more can you possibly want? You must admit on trust all that I choose to invent for you, while all the time I admit that it is quite inexplicable - "no one onght to feel surprised at all this." Take my word for it.

I believe that the title I have given to my book, "On the Origin of Species," is not a false one, though it tells nothing as to the origin of my "origin," where there could by no possibility have been any selection, nothing to select, nothing to select from.

I believe that as we possess (viz., in my doctrine) only the "last volume" of the "geological record," although the difficulties of my notion are "inexplicable," I can make them "disappear." No doubt I have to beg the whole question, but that is the only sort of logic that I care to be guided by. I have furnished my library from the land of dreams, and I much prefer it to the volume of the "Testimony of the Rocks." The latter I own is in existence, while no page of mine is to be found, except in my own brain; but "I am of the same opinion still."

I believe that Geology giving us no traces of the existence of "infinitely numerous" gradations of extinct species is "the most obvious of the many objections which may be urged against my views," but what have I to do with that!

I believe that the remains of the horse and of the tapir are found in the same formation, but for all that I hold that there must have been innumerable links between them, though not one of them has ever been found.

I believe that geology tells us truly all about the large and the small genera, but nothing about all the intermediate species which must once have existed because I choose to say so. You may call this what you like, but that is my opinion, which is final.

I believe that no trace even of such organic life has been detected in the basement of the strata of the rocks, it being destitute of the remains of any animals, so that I have no evidence of my theory, but it matters not. Evidence to prove it is not wanted by a person like me. I maintain that it is indubitable that life swarmed in that primitive region, though we only meet with the lowest creatures at the lower 
part of the next, and with nothing higher in the scale of creation than fishes in even the upper part of it. Never mind that; facts are not stubborn things when they have to do with me. I make them all bend and yield to me. Veni, vidi, vici!

I believe that there must have been some ancestor of the trilobite, "which probably differs from any known animal," long before that curious creature; but for proof of it I refer you to the invisible world, whither no one has yet travelled to find it. What more would you have?

I believe that these most ancient of old rocks, whose existence you will find ample proof of in my "imagination," were "somcrhere accunulated," but where that "somewhere" was or is I am not going to tell you, so you may save yourself the trouble of asking me.

I believe there were and are such rocks many miles thick, if only we could find them.

I believe that the sudden appearance of whole groups of species in some strata by no means overturns my doctrine of slow descent by natural selection, though Sedgwick, Agassiz, and others have maintained that it does. What does anyone but myself know about the matter? Geology as at present understood must be false if my Theory is true, and as my theory must be true because it is mine, e'en so let it be. Fiat Erolutio, ruat calum.

I believe that though geologists teli us that certain animals cannot be found in any geological formation before certain periods, which is tantamount to a high probability that they never did exist in them, I assert that they did exist, basing my assertion on the main stay of negative evidence.

It is true that when it suits my purpose I can turn round and argue that negative evidence is worthless.

I believe this is not too barefaced a piece of contradiction to palm off on the credulity of weak-minded persons.

I believe that the geological record is imperfect to an "extreme degree," but if you can bring yourself at my dictation to disbelieve the facts which geology does attest, then you see you will take in my theory, and si populus vult decipi decipiatur.

I believe that the extinct rhinoceros was more advantageously organised than the existing one, so that it ought, on my theory, to have "infallibly exterminated the inferior ones." The contrary is before me, but black I always make white when I choose.

I believe that in the race for existence the weakest must succumb to the stronger, though I see before my eyes that the whole of creation contradicts this.

I believe that there must have been, and therefore were, an infinite number of previous forms of the large elephant and the mighty mammoth, though the fragment even of the remains of not one of these has ever been discovered, while those of the most fragile and delicate shells are found in abundance in the chalk in the lower rocks.

I believe anything and everything as it suits my purpose.

I believe that natural selection selects itself, that nature has a "power of selection," that she is more powerful than "feeble man," so that if he can do so much in improving animals, why can't she do all I choose to imagine, only time enough be given beyond the power of imagination.

I believe that if feeble man can do so much, I can see no limit to the amount of change, to the bcauty and infinite complexity which may be effected in the long course of time by "Nature's poner of selection," so that "powerful" nature is superior to feeble man. It is true I have argued elsewhere that natural selection spurns beauty, and that if it 
did not, my theory must fall to the ground-never mind that-I stand and fall myself by my theory.

I believe that though man does appreciate and admire beauty, whether in form, colour, harmony, or any other mode, monkeys do not, so that if you ask me kow man, who has come from the monkey, has come by this faculty, which the monkey has not, I must decline to answer the question.

I believe, I say, that natural selection improved us by giving us the power to value beauty which she herself ignores and sets aside. You may say this is nonsense. You may say so if you like. I have said it, and I mean to stand by it.

I believe, on my theory, that Nature makes species; but that man can only make varieties by culture. It is mere assertion. and the argument, if carried out, annihilates my theory. Let it do so if it likes -what care I? I beliere that "if nature had to make" the bill of a pigeon short, it would be a slow process indeed, and you would see all the young pige ns in the eggs striving with one ancther to see which could come out with the shortest and strongest bill. If you can't see this you must be very dull indeed-in comparison with me. I have said elsewhere that natural selection is only the "sequence of events." It might perhaps take ten thousand million years to make one bill strong enough, so that the whole brood would have been dead and gone thousands and millions of years before the necessary degree of strength could be arrived at. I am not able to reconcile these palpable and gross contradictions; it is quite enough for me to be able to swallow them and any number more.

I believe that the old-fashioned Book which tells us that "we are but of yesterday, and know nothing" is quite out of date. thing.

I believe, on the contrary, that we are of to-day, and know every-

I believe that though I was born with a bee in my bounet, I am descended from a monkey and not from a bee, for all its wisdom of instinct.

I believe that natural selection is " a power incessantly ready for action" upon a creature, and therefore sometbing outside it, while in reality you will say it is plain that it is nothing but the working of the creature itself. In other words, unless some at least of the offspring inherit any chance advantages, nothing can come of them, viz., that advantages cannot be inherited unless they be inherited. This I consider a weighty and powerful argument, and not a most sapless piece of scribblement.

I believe that "non-inheritance of auy character is, in fact, the same thing as reversion to the character of the grand-parents or remote ancestors, and no doubt this tendency to reversion may often have checked or prevented the action of natural selection." I hear you say, "No doubt at all about it!" I don't care what you say, I must stand by my theory, thongh it leaves me in the lurch.

I believe that "it inevitably follows that as new species are formed through natural selection, others will become scarce or finally extinct." I can't deny that you and all other animals seem to continue as you and they were since the day you tell me they were created, and that elephants, horses, lions, tigers, and all the rest do not change into one another, nor can I point to a single one in the process of changing. You may laugh at me when I say that for all that they do, but it is no laughing matter for me to have my theory overturned by facts, so all my vagaries must be as they are.

I believe that by natural selection a bustard becomes changed into an ostrich, a horse into some other animal, and so on, because I see 
that man has created many hereditary varieties, such as the different kinds of dogs, and though these are only varieties, as is proved by their breeding together, their nature not being changed but having a tendency to reversion, I am determined not to give up my notion, groundless as this shows it to be.

I believe that man "creates" these varieties, but I cannot allow any other creator but that of my own creating.

I believe that the ": action of natural selection will depend on some of the inhabitants becoming slowly modificd. Nothing cun be effected unless favourable variations oeeur, and variation itself is always a slow process." What I mean is, that unless animals or plants begin to change, they never will be changed. A very recondite argument, is it not?

I believe, I "suspect," that an "occasional intercross with a distinct individual is a law of nature. I am well aware that there are, on this view, many cases of difficulty, some of which I am trying to investigate." Right or wrong, therefore, you must take for granted that any difficulty either has been or will be solved by me. That is a matter of course.

I believe that if I only "suspect" a new law of nature, a new law of nature there must be.

I believe, that is to say, that this new law brings about cccasional exceptions only occasionally. That I consider a grand discovery, worthy of Aristotle, Pliny, Plato, or Solomon himself.

I believe that the several species of a genus "must have proceeded from the same source, as they had descended from the same progenitor," although " undoubtedly there are many causes of extreme difficulty in understanding how the same species could possibly have migrated from some one point to the several distant and isolated points where now found." For instance, "why do we not find a single animal common to Europe and Australia and South America?" The conditions of life are the same. The answer, I believe, is that the animals have not been able to migrate. I grant you that there are as many animals in each of the same genus as formerly, and which must, therefore, have "descended from the same progenitor." There they are; they can't have migrated. They must have been, I say, separately created. Yes, there they are! I do not, either, believe that continents "which are now quite separate have been continuously, or almost continuously, united with each other; so that I do not "for a moment pretend that any explanation could be offered of many such cases, but as they or my theory must give way, I need not say which must do so. My theory, it is true, here fails to explain the very point it undertook to interpret; but never mind that. I would call it a miracle, only that I don't believe in miracles.

I believe in a bear "swimming for hours with a widely open mouth, thus catching, like a whale, insects on the water." "Very like a whale!" I think I hear you saying, but I can't help it if you do. "I see no difficulty in a race of bears being rendered by natural selection more and more aquatic in their habits, with longer and larger mouths, till a creature was produced as monstrous as a whale." Don't laugh, I beg you. It's all of a piece with my whole argument, for I have said all along that it is easy for natural selection to fit any animal for any changed habits whatever. "It is difficult to tell, and immaterial for us, whether habits generally change first and structure afterwards, or whether slight modifications of structure lead to changed habits." How can I tell you? All is fish that comes to my net.

I believe what I have just said, though it may perhaps be suggested that if the bear was determined to live in the "dark unfathomed caves" 
of the ocean before he was quite fitted for it, he might find that natural selection had led him into a somewhat awkward mistake, not much to his benefit; or if, on the other hand, he had to wait abore till he was fitted to go down below, he would fare but badly and on very short commons among the mountains and forests. A demi-semibear-cum-whale would be perhaps rather an "odd fish" to look at, but then, you see, it is quite as easy for you to swallow my story of the bear as it is for the bear to swallow the flies, so you ought to be very much obliged to me for telling you so very pretty a fairy tale.

I believe that if an animal or bird has more than one habit, that is a proof that it is in a transition state. Why not believe in a transmigration of bodies as well as in $n$ transmigration of souls?

I believe, therefore, that as a dog sometimes eats grass, it shows clearly that in due time he will turn into an ox; and just in the same way as the reindeer sometimes devours the hamster, so is he sure to turn into one or other of the carnivora. I can't exactly at present say which, but if you wait long enough you will see it to be as I say -no doubt about it.

I believe that when the buffalo is floating under the water, with only his mouth out, for some hours at a time, natural selection is "at play," and has her eye upon him with a view to his becoming this, that, or the other, as the case may be.

I believe that Shakespeare must have been of my way of thinking, for he gives his well-known character in the Nidsummer Night's Dream an ass's head, who then naturally enough says, "Methinks I have a great desire for a pottle of hay : good hay, sweet hay, hath no fellow." So that you see when a man is turned into an ass, he will be sure to like thistles in the end, and to bray like a donkey as he must be.

I believe, "I see no difficulty in believing," anything at all that comes into my head, and you must do the same, without expecting any proof from me.

I believe, it is with me a sine qua non, that "in order that any great amount of modification should in the course of time be produced, it is necessary to believe that when a variety has once arisen, it again varies-and so onwards." That is to say, you must take all this on credit; for I have no proof of it, and therefore can give you none. You must take assertion for proof, and is not that enough for any one? It may be a novelty in a scientific enquiry, but with that you have nothing to do. Leave it all to me.

I believe that " many ancient forms of life have been utterly lost." Therefore I must needs allow that they can never be found, and so much the better for me, for then I can desire you to "readily believe that the unknown progenitor of the vertebrata possessed many vertebræ." I cannot take upon rne to say that he acquired them by natural selection, for he must have had them all, at once or not at all. I cannot help allowing that the vertebra began with a sort of rudimentary one with a view to the future benefit of the animal, and though this is the very thing which all my theory goes against, it even must be so, but I hold to my theory for all that.

I believe that "every single organised being around us lives by a struggle at some period of its life." "The merest trifle would often give the victory to one organised being over another." "If any one species does not become modified and improved in a corresponding degree with its competitor, it will soon become exterminated." It is true that, as you may see in any wood where the trees if thickly planted together try each to overtop the other for the sake of light and air, no new species are produced, but the survivors remain of the same kind as before ; but I am "of the same opinion still," and though facts 
are against me, I am against facts. I have nothing to do with them in any such case.

I believe that all living beings have this struggle against each other, and that the weaker inust go to the wall and be exterminated, although I see that all sorts keep their own places as of old, and that the weaker of countless kinds, such as the herring, still exist in innumerable numbers, so to speak. It is a most defenceless creature, and must have been overlooked and neglected by natural selection, for still it flourishes and abounds beyond all calculation. This fact you may say is too much for me. Not so, I am too much for it.

I believe that the forms are so nearly balanced that things remain in statu quo "for a long period of time," in fact for unknown ages; so that it would seem as if the result of some omniscience which saw into all futurity beforehand, had arranged for the general good of all, but for all that I hold that natural selection still acts and always has acted for the benefit of individuals only.

I believe that the order of Nature is and always has been well balanced, though arranged by no superior intelligence, whils numerous destructive creatures let loose by natural selection to live by destruction, are still, as always before, neither too many nor too few.

I believe that "the modified offspring from the more highly improved branches in the line of descent will, it is probable, often take the place of, and so destroy, the earlier and less impioved branches ;" but I cannot tell you what I mean by "improving animals," nor when an animal is "less improved" than it ought to be. I cannot tell you of any animal that would be better for improving, nor what improvement it needs, nor how I would improve it. How can I tell you when I have elsewhere said myself, "Who will pretend that he knows the history of any organised keing sufficiently well to say whether any particular change would be to its advantage?" And, again, "What advantage would it be to an earth-worm to be highly organised?" No, I cannot tell you what advantage it would be to a camel to be turned into a lion, or an ostrich into a hawk.

I believe, however, for all that, that "the ultimate result will be that each creature will tend to become more and more improved in relation to its condition of life." No doubt thesc assertions are self contradictory, but so let them be.

I believe, yes I believe, that this improvement will take place with the greater number of beings throughout the world. You may reply that in that case there would in time be no more natural selection, her work being done; and you may ask me what will be the next step? Possum non mi recordo.

I believe in these improvements and transformations, but I cannot at present explain to you how a transformed animal is an improved one. You may say that a camel turned into a horse is not therefore "improved." If I choose to say it is, is not that enough?

I believe in all such metamorphoses, though I have no answer to give to the question how, if an elephant were to be changed into an ass, it would be improved, its superior intellect being lost by the exchange.

I believe in them, I say, because I believe in them, although you may ridicule my idea of improving Nature, and may consider it as misplaced and audacious as to attempt a new creation, and may ask me what is to become of all the living creatures when they have been "improved" up to the status of man?

I believe it is not the veriest nonsense, though I cannot tell you whether they must all become men in form as well as in sense, or must remain in appearance what we see them to be now. You may 
consider it an idle and preposterous dream, but I consider it a wonderfully clever and sensible idea. What a world it will be when every animal is "levelled up" to the rank of man, and every man still higher to that of a Darwin! Then you will say surely that the " height of folly can no farther go." But that folly is yours in thinking so. I take my stand on my own superior wisdom.

I believe it all, yes, I believe it all, although I see that with what I hold to have been done in the countless past ages in the way of metamorphosis, elephants have not yet been turned into horses, nor bears into whales (though "very like" them), nor ducks into swallows; and that the ass, the gander, and the goose still survive, the one to bray and the other to cackle, even like some "men of science."

I believe that I can clear up the "mystery of mysteries," as it has been called by one of our greatest philosophers, the origin of species, although "I have found to my cost a constant tendency to fill up gaps of knowledge by inaccurate and superficial hypothesis."

I beli?ve the varieties are "as steps leading to more strongly marked and more permanent varieties, and these latter leading to a sub-species, and so to species." "Hence, I believe, that a well-marked variety may be considered as an incipient species." You may say, on this, that I hold permanency to be an attribute of species, and not of variety; and you may ask me, why, if they are essentially the same, they trouble themselves so much to make a change, and that for no object? That is for them to say, not for me.

I believe that varieties "become ultimately converted into good and permanent species," which "differ from each other far more than do the varieties of the same species." You may ask me what I mean by the term species, but as I do not know I cannot tell you. All I can say is, that to discuss the question before a definition of the terms has been asked is "vainly to beat the air." This I apply to you, but I cannot for a moment allow it to apply it to myself. Such a thing must not be thought of.

I believe that it would be a "vain search" to seek for the "essence of the term species." Nevertheless, I elsewhere state that "good and distinct species". unquestionably occur.

I believe that Mr. Gould is utterly wrong where he says that "the gorgeous colouring of the humming birds has been given for the mere purpose of ornament," "in other words, that ornament and beauty, merely as such, was the end proposed." That is "absolutely fatal " to my theory, consequently I cannot for a moment admit it.

I believe that species are "permanent varieties, and that this is a characteristic of species," that they always remain the same, which it is the object of the whole of my book to disprove. But let that pass.

I believe that "one hand has only worked through the universe," but I labour in all my works to disprove it. "One is apt to wonder why a distinct species should have been created," but "we see whole series of animals which have been created." Nevertheless, I utterly disbelieve in creation.

I believe that I am right in my view, in opposition to John Hunter who held that no proof has ever been obtained that a hybrid race can continue. In opposition to De Candolle, who states that "permanent differences cannot be referred to any one of the actual courses of variation, and that these differences are what constitute species ;" in opposition to Lyell, who wrote that it cannot be shown that a single permanent species has ever been produced by hybridity; in opposition to Lawrence, who says that "we must admit for all the species which we know at present a distinct origin and common date ;" and in opposition to Cuvier, who declares that there is no difference whatever 
between the remains of animals embalmed in Egypt of old and those of the "present aay."

I believe that Sir Charles Lyell was utterly wrong when he wrote that "species have a real existence in nature, and that each was endowed at the time of its creation with the attributes and organisation by which it is now distinguished."

I believe that I may manipulate the word "species" as I like, and that I can play fast and loose with it as I please; that I can make use of it or discard it as it suits my purpose, and make the most of the differences between some naturalists as to whether certain supposed species are really species or only varieties.

I believe that inasmuch in very many cases one form is marked as a variety of another, though in the absence of the intermediate links, on the ground that any analogy that may be supposed to exist somewhere "or may formerly have existed," therefore I may open the door of my fanciful imagination as wide as I please.

I believe that, during "vast, yet unknown, periods of time, the world swarmed with living creatures," of which not a vestige or trace is to be found. "I believe this to be indisputable," though, as I have just said, "quite unknown," but I can never allow any opponent to argue anything from conjecture; certainly not. That prerogative is for myself alone.

I believe that-it is, perhaps, impossible to bring forward one case of the hybrid offspring of two animals clearly distinct, being itself perfectly fertile.

I believe that I may argue as I please in the teeth of this fact, but if a brother naturalist gives an argument from it, that cannot be allowed for a moment, "though it must be confessed that we cannot understand, except by vague hypothesis, several facts with regard to the sterility of hybrids. Nor do I pretend that the foregoing remarks go to the root of the matter. No explanation is offered why an organism, when placed under unnatural conditions, is rendered sterile." In other words, I stumble at the threshold when pretending to explain the origin of species, and am hopelessly low in the labyrinth of error in which I have involved myself.

I believe that the sterility of hybrids "could not possibly be of any advantage to them;" but as I hold that natural selection has done everything that has been done in nature, or almost everything, and all for the good of the creatures, you may ask me if sterility did not originate by natural selection. By what other means was it introduced? But for this I must refer you to any other person who may be able to answer the question, for I am not.

I believe that natural selection had no hand in sterility, for it could be of no advantage to any creature, and yet sterility is a law of Nature. This, it is not for me to explain. I must leave it for Nature and natural selection to settle that question between them.

I believe, I say, that sterility " could not possibly be of advantage to animals," but for all that I have laid it down (emphatically) that the sterility of the worker bees "has been advantageous to the community." You may call this blowing hot and cold, but that is my affair.

I believe that all varieties of dogs are "descended from several wild species," though naturalists think otherwise; but as they differ from me they must be wrong, for I must be right.

I believe that though they all breed together now without sterility, yet it was not so at first. This may be a petitio principii, but so let it be.

I believe that "new races of animals and plants are produced under domestication ;" but I do not allow this to be the case with dogs, for it does not suit my purpose. 
I believe that it is " a strange arrangement" of Nature to "grant to species the power of producing hybrids," and then to say to them, "Hitherto shalt thou go and no farther :" "No road this way." I could have done much better than Nature, and my path is, in my own opinion, a much better one than the old high road. You may think that "species have been endowed with sterility simply to prevent their being confounded in Nature. I think not." That settles the matter.

I believe that those who are opposed to me as to the question of sterility "slur it over" as beyond their " reasoning powers," though it must be confessed that we "do not understand, except on vague hypothesis, several facts with respect to the sterility of hybrids," and as to myself "no explanation is offered of it." You may consider this as a confession of my own ignorance as being as great as your own about the matter, but what is ignorance in you is wisdom in me when spread over many pages of high-sounding talk.

I believe that on my "principle of natural selection," both animals and plants may have been developed "from some "low form" of sea weed ; and "if we admit this," which I shall henceforth take as proved, we must, of course, "admit" that "all the organised beings have descended from some one primordial form." In other words, my theory being thus conclusive you may have done with a CrEator. Natural selection is the creation of my brain, and the only creation that I mean to admit of. 'This is my Book of Genesis, and no other can be admitted as true. This is a specimen of my reasoning powers. If in law there is a "Coke upon Littleton," why should there not be in logic a "Darwin upon Whately?" Why not? Echo answers, "Why not?"

I believe that "natural selection is a power incessantly ready for action, and is as immeasurably superior to man's feeble efforts as the works of nature are to those of art." In other words, as, according to me, Nature and natural selection are all one, it results that Nature's works are as superior to man's as Nature's works are. This is a notable discovery, is it not? At all events you will allow that it is worthy of me-of me, C. Darwin.

I believe every useful variation is " preserved by the term natural selection;" as for instance, that "the swiftest and slimmest wolves would have the best chance of surviving, and so be preserved or selected." You may, if you like, call this a figure of speech, as if one were to say that when a ship is wrecked and a hundred of the crew are drowned out of two hundred, the other hundred are " selected." Well and good. All is well that ends well. Certain animals continue to exist. That is the great discovery that I have made.

I believe that though geology "does not reveal" any traces of the "missing links" in my chain, which, however, hangs together to my view just as well without them as with them, yet that it ought to have recovered and revealed them, which, in my judgment, comes to exactly the same thing

I believe that "certain forms are supplanted by new ones." True this does away with the belief in the power and wisdom of a CREATOR, but that you will never miss in the terra incognita of my discovery.

I believe, "I can see no reason to doubt," "that all the various gorgeous tints of birds" (and so, no doubt, of insects and fishes, too) were organised by the admiration of the females for the first " feather in the cap" of this, that, or the other cock bird. You may ask me how on this supposition I account for the black colour of the crow, and the dingy hue of the coot. You may ask me how I account for the young birds not having the gay and gaudy colours which they attain oftimes. You may ask me how I account for the fact that some species of birds, as, for example, the crossbills, have every variety 
of colour in one kind, green, blue, red, orange, yellow, "mille trahens varios adverso sole colores." Yes, you may ask me, but your question reminds me of the poet and his suggestion of the reply to "calling spirits from the vasty deep," "will they come when you do call them ?" "Ay, there's the rub!"

I believe that natural selection has "given the proper colour to grouse" and other birds and insects for "preserving them from danger," but I do not not tell you how they did before they " selected" their present colour. I cannot condescend to answer any such questions.

I believe that their colours were produced by the "aggregate action and production of the sequence of events," or, in plain English, that we see them as they are, and that is the reason of their being so. What would you have more? You may ask me, as I hold that natural selection is vastly superior to any art or skill of man, whether a watch or a steam engine is the "result of the aggregate action and product of the sequence of events?" I am quite above replying to the enquiry.

I "see no greater difficulty" in natural selection giving wings to seeds than in a planter improving his plants, but I cannot tell you how they come to be. It is enough for me to have them ready-to-bemade for my theory.

I believe that the ostrich came from a bustard, by using its legs more and its wings less, until it got to have no wings to fly with. I do not pretend to tell you what it has gained by this loss. You may say that wings would be very useful to it, hunted as it is. That I cannot help. My theory requires it to be as it is. Whatever is, is. That you cannot dispute.

I believe that bustards still exist, though elsewhere I have said that in all such cases of improvement by natural selection the original species is "exterminated." You may ask me to reconcile those two contradictory statements. It is no business of mine to do so. You must take things as you find them, for me.

I believe that a wingless bird comes by degrees, though we have never seen the "transitional grade" to be the first to "float along the surface of the sea," and "ultimately to rise from its surface and glide through the air." I hope you do not mean to doubt this, for I myself am a standing proof of a far greater flight of fancy than even this.

I believe that all this is much more scientific than the opinions to the contrary held by such men as Cuvier and Owen, Agassiz and Phillips, Jones and Sedgwick. They never knew how to interpret Nature as I do.

I believe that a "well-developed tail" in an aquatic animal might " come to be worked in for all sorts of purposes" in a land animal. But how it came to be formed in the aquatic animal, this deponent sayeth not. Natural selection being an exceedingly slow process, these aquatic animals must have been for thousands of millions of years without any tail at all to begin with. No doubt, in time, they began to be formed, or rather to form themselves. It is true that a fish without a tail must have been a queer sort of a creature, an "odd fish," perhaps you will say. You may say what you like, but "all is fish that comes to my net." So it was before "their tails were formed," so it was in those "good old times," and so it came to pass that in due time the tail of a shark got to be "worked in" for the tail of a cow, and that of an herring for that of an ass. All a priori to posteriori. C'redite posteri!

I believe that "it certainly is not true that the new organs appear suddenly in any class ;" but if you had had a microscope of sufficiently strong power, let me tell you, you would have discovered if only the 
hundred thousandth part of such a tail $a b$ initio in the cow, the giraffe, or the ass, just as I have said.

I believe that it was so, though what conceivable use it could have been to that animal as a "fly-flapper," even when it grew to be an inch long (for I do not pretend to say that it came per sultum), you must ask some one else to tell you.

I believe the same, the very same, of all the other parts of animals, mutatis mutandis, such as the trunk of the elephant, the horn of the rhinoceros, and the hoof of the horse, \&c., sc., sc. Neither Aristotle. indeed, nor Pliny, Buffon, nor Linnæus ever thought anything of the sort; but what of that? I do, and that is enough for me, and if it is not enough for you, it is all I can offer you.

I believe that as many aquatic creatures have become land animals so many land animals were once upon a time denizens of the sea. That as the giraffe was once a fish, so, as I have elsewhere said, a bear became a whale, or uncommonly like one, "catching flies ;" possibly, as the thought just strikes me, the ancestor of the flycatcher, the bird so called-who knows? You may tell me that it would be a curiosity in its way. No doubt about it, but being dovetailed (apropos of tails) into my theory, it must have been so Don't ask me to give up such a convenient argument for making up my book. Non possumus.

I believe, "I see no difficulty in a race of bears being rendered by natural selection more and more aquatic in their structure and habits, with larger and longer mouths, till a creature was produced as monstruous as a whale." I repeat it if I can get you to swallow this as easily as my bear did his flies, well and good; if not, I can only say that it has all gone down with me and my brother philosophers. True, this wonderful creed, as promulgated in my first edition, having been ridiculed by the Rev. F. O. Morris in his "Difficulties of Darwinism," I have thought it expedient to omit that from the next edition of my modern "Metamorphoses," but only as a suppressio veri.

I believe all the time that this is in harmony with all the rest of my story-book, and as such no doubt you will not consider it as a whit more ridiculous than all the rest of it. I leave it to you to strike the balance of absurdity, as you consider it, between my title oage and my "tail-piece." Have I not Horace on my side, where he writes, Desinit in piscem mulier formosa superne?

I believe that, as elsewhere I make fishes go on land to become land animals with tails, so I can make my land animal go into the water to grow his tail.

I believe that the penguin and the ant, the hog and the swallow, the camel and the kingfisher, the porpoise and the bat are, one and all, as well as ourselves, " joined together by family ties," though from what common ancestor they spring is not certain. Certain, however, it is that something of the sort took place, me judice.

I believe that our having all this mixed blood in our veins, may perhaps account for the different dispositions we see in ourselves, our friends, and relations; who can tell? I grant you that it may be rather hard to prove it; but that is no concern of mine. All I have to do is to propound theories, and the more outrageous the better for me and my book.

I believe that an "ideal similarity," leading to an ancestor of which we know nothing, is, or ought to be, very convincing.

I believe, "I see no good reason to doubt," that when "males and females of any animal differ in structure, colour, or ornament," the admiration of the females for such has producedthe apparently different species we see. I admit that though I have elsewhere stated that natural selection always works for some useful end, there is no useful 
end in all this, except in a "forced sense," but I have set forth the theory, and by it I mean to stand or fall.

I believe all this, I say, although I have somewhere or other stated that "natural selection cares nothing for appearances," and that if it were true that many "structures have been created for beauty in the eyes of man or for mere variety, THIS DOCTRINE, IF TRUE, WOULD BE ABSOLUTELY FATAL TO MY THEORY." You may say that if this be not self-contradiction and self-confutation, you do not know what is. Perhaps you do not, but you must allow me to decide.

I believe, for instance, that one peacock having by some lucky accident come by a new feather of striking appearance, became at once an object of great attraction to the lady-birds about him, so that the next eggs laid hatched out an improved peacock. No doubt about it. No doubt about it; only see it as I do, and you will see what you will see. "Some naturalists believe" that this is nonsense. All naturalists, do you say? all mankind? Let them say what they like, and think what they like, what is that to me?

I believe it all ; I " see no good ground to doubt" it, although it "should appear childish to attribute any effect to such weak means." Thus you may get at the mental, if not the moral, qualities of birds by the "help of the imagination "-the "imagination" according to Tyndall.

I believe it, I say, again and again, though you may ask me how it came to pass that the admiration was all so on one side, and that the gentleman birds had no such admiration for the "lady-birds," very ungallant, you say, do you? Well, perhaps it was ; but then, you know, de gustibus non disputandum, "when a lady is in the case." Nor can I tell you how it has come to be very much the opposite with mankind, descended as we are from monkeys, or cock sparrows, or what not. I allow that the courting is on the side of the male; but they must change sides for my argument.

I believe, "I do not doubt, that some domestic animals vary less than others, yet the variety or absence of distinct breeds of the cat, the donkey, gonse, \&c., may be attributed in main part to selection not having been brought into play." Don't laugh. Its no laughing matter. It may be a difficulty with you, but it is none with me, though it seems (to you I say) very unaccountable that no change should have taken place in these interesting animals-the cat to wit, with all its caterwauling -in all the millions upon millions of ages that my theory supposes, down to the present time. Nor is it any difficulty with me that, as I allow, the cats in the mummies of Egypt are precisely the same as those of to-day; for what is five thousand years in my scale of time?

I believe that "the goose seems to have a singularly inflexible organisation." It is a bird that is too much for natural selection. I am sorry for it, but I can't help it.

I believe, "I can see no difficulty in natural selection preserving and accumulating variations of instinct to any extent that was profitable. It is thus I believe that all the most complex and wonderful instincts have originated." Once on a time, I mean, bees had no such instincts as they have now ; nor had ants, nor migratory birds. At that early date natural selection had not been "called into play."

I believe that the spider was once without the instinct which now prompts it to spin its web, without the legs it now has, without the habits it now has, without its spinnerets, and therefore without the power of catching insects to live on. How it lived then, I am not quite prepared at present to say, nor whether it was a spider at all or not. Nor can I say, as to its "complex instincts," how it could have done with only the beginning of a web to support it through all the 
thousands and millions of ages that it took to come to its present state. You may suggest that it must have been created a spider to be able to act as a spider, but that does not fit in with my notions.

I believe that originally the "fertile males and females of the same community transmitted to their fertile offspring a tendency to produce sterile members." How there could have been a community of the kind we now see without any sterile members of it, all being ferile, I do not explain. You may call my theory a mere fable and idle dream, but in my own opinion it is worthy of Aristotle himself.

I believe that while some of the fertile females of the community were transforming themselves or their offspring into sterile members for the benefit of a future society which did not then exist, some one female was acting in the opposite direction, for the production of a mother general of the whole hive; in other words, that their opposite instincts were "coming into play" at one and the same time, in one and the same community. You can, no doubt, at once see the probability of it just as I do-that, in fact, sterility came from fertility, sterile grandehildren from fertile parents and grandparents, and, vice versâ, a still more fertile queen from the same source. This is one of the ways in which I prove my theory.

I believe, as I said, that a "slight modification in instinct * * * has been advantageous to the community." I cannot deny that this is, in fact, to beg the whole question, a "change of instinct" being only an idea suitable to a fairy tale, but by me thought as easy a thing as for one to open and shut a book. How can I doubt, since it suits my theory, that at the proper moment "certain members of the community " foresaw the benefit to it of sterility, and were so very accommodating and obliging as to agree to have sterile grandchildren all but some one who remained fertile to the admiration and loyalty of the rest of the society.

I believe in the "long continued selection of the fertile parents," but who they were selected by I do not say, beyond that it came to pass in the sequence of events. It is thus I make words the factors of my system.

I believe that the whole of the polity of the honey bee has come to pass out of nothing at all of the kind, although the figure of it is to be seen in Old Egypt exactly the same as it is to be seen now. But it must be as I say. Sic volo.

I believe that " if the Mexican bee had made its spheres at some given distance from each other," and "if she had made them of equal sizes," and if she had "arranged them symmetrically," and if she had made them " in a double layer," then the comb would "probably" have been as perfect as the comb of the hive-bee. All this, "if we could slightly modify the instincts already possessed" by the Mexican bee. Then "we must suppose her to make her cells truly spherical and of equal sizes ;" we must suppose her "to arrange her cells in level layers ;" "we must suppose that she can somehow accurately judge as to what distance to stand from her fellow-labourers ;" and "we have further to suppose," "but this is no difficulty" (to me), that she can "prolong the hexagon to any length requisite" (only five suppositions, a mere trifle in such a book as mine), and then you will see what you shall see. Talk about Ovid and his metamorphoses, "nauci, rauci, pili, nihilo cestimo." You tell me that all this reminds you of $\mathrm{Mr}$. Thornhill, in the "Vicar of Wakefield," and his "Hence I shall proceed to observe that the concatenation of self-existences, proceeding in a reciprocal duplicate ratio, etc., etc."

You may tell me what you like, but facts cannot alter fancies, can they? Answer me that question, if you can. You say that if I can 
effect all this, beginning only to "slightly modify" an instinct, I can do as much as the magicians of Egypt, or the wizards of the Arabian Night's Entertainments. Of course, I can ; "wonders never cease" in the creations of my brain. I grant you, if you put it to me, that in like manner, by only "slightly modifying" the instincts of the sheep, it would in due time, by a touch of my wand, heigh presto! be turned into a wolf. That is my mode of philosophical enquiry, though you may think it a preposterous series of assumptions, all purely imaginary and utterly incapable of proof, strung together in the attempt to cancel Creation and so ignore a Creator.

I believe that "it seems at first quite inconceivable how bees have practically solved a recondite problem," but I can soon get over such a trifle as this, or the equally slight apparent difficulty how the spider came to construct its web (on my theory), or how the tailor-bird learned to sew together leaves to construct its nest, or to whom the beaver served its apprenticeship in the art of cutting down timber and building a house, and so on through all the instincts of all the creatures of Nature. I hold that "the difficulty is not nearly so great as it at first appeared." Oh, dear no! Shew me the difficulty that I cannot ride over on my hobby. I will thank you, I say, to show me any such.

I believe, as I said, that bees have learned by degrees to "strike imaginary spheres," being able "somehow to know the proper distance" to work at. You may reply to this that if carpenters and masons were to "strike imaginary spheres," and "somehow" to ascertain the "proper distances" without rule or plummet, they would be likely to make but a bungling job of it. I pass that by ; all I say is that the bee imagines a circle which it never really sweeps, knows when and where one such circle meets another, and builds its building on these baseless dreams.

I believe that natural selection has by degrees, in untold ages upon ages, led the hive-bee to make its comb "absolutely perfect in the economising of wax." It may be a difficulty to you, but it is none to me, that swarm after swarm must have been hatched with new instincts, a queen producing 20,000 eggs capable of "striking imaginary spheres," suggestive to modern philosophers of striking out the most wild freaks of the imagination to be set forth in due time in a mere jingle of words making a pretence to science. Supposed facts, in my opinion, are to be established by the "use of the imagination" inventing phenomena which have no real existence, taking for granted what had to be proved, and by the unlimited use of inaccurate language enveloped in a cloud of words involved as much as possible.

I believe all I have said about the bees, and I do not consider that it is for me to explain with whom or with what they have to struggle, the humble bee doing just as well with its rough architecture as the Mexican bee with its mathematical construction, and wanting no improvement, excepting in the brain of a "philosopher."

I believe that we ought never to refer to final causes, though Dr. Whewell says we cannot help doing so, as we prove by ourselves often using such expressions as Nature's " designs" and "her objects," protesting all the while that we only use them in a "wide metaphorical sense."

I believe that Sir Charles Lyell was quite wrong when he said that "species have a real existence in Nature," and that each was " endowed at its crcation" with its present attributes, because, he says, "we must suppose that when the author of Nature creatcs an animal or plant, all the possible circumstances in which its descendants are destined to live are foreseen."

I believe in the transmutation of species, though Sir Charles Lyell holds that the argument from the brain in the young of animals lends 
"no support whatever to the notion of a gradual transmutation of one species to another," least of all "from an animal of a more simple to one of a more complex structure."

I believe that Sir C. Lyell was talking at random when he said, speaking of a philosopher like me, "Henceforth his speculations know no definite bounds; he gives the rein to conjecture, and fancies that the outward form, instinctive faculties, nay that reason itself may have been gradually developed from some of the simplest states of existence. That all animals, that man himself, and that irrational beings, may have had one common origin."

I believe that male and female apes must have become simiamultaneously endowed with the reason of man; for, if not, the one that had such reason could not have consorted suitably with one that had not, and such pairs, to be well matched, must have arisen contemporaneously for several generations, or there would have been a reversion to the ancestral ape, which never, since the world began, could light a fire or cook its food, make a bow and arrow, or even a hoop.

I believe all this, although I cannot deny that the dog or the elephant exhibits far more of the human character than the ape, and that there never has been, and never can be, any friendship or communication between man and an ape such as there is with the dog or even the wolf, and that the ape can never be trusted by man, or be made useful to him, as the dog, the horse, and many other animals can.

I believe all this, I say, although it will be no use for me to deny that the common bee closely resembles man in its classes, its government, its laws, its public zeal, its loyalty, and its architecture; in not one of which respects does the ape even approach to it, much less to us.

I believe that our speech has its origin in the tones of the voices of birds and beasts. You may ask me how, if so, it is that being so much nearer to the ape than the nightingale, we do not screech like the gorilla instead of singing as we do; but I consider such a question quite irrelevant to my grand argument.

I believe that Agassiz was quite wrong when he stated that there is nothing like parental descent connecting the line of creation; that Cuvier, to the same effect, was also equally wrong; and Owen also in his notion that the foreknowledge of such a being as man must have existed before man appeared or could appear.

I believe that the wing of the bat, the thousands of lenses of the eye, the electrical organs of fish, and all such wonders of Nature were the results of natural selection, or to speak more plainly (?), by "development," "plastic tendencies," "slight modifications," "generative variability," and so on. No doubt you must see all this as clearly as I do. I have rather unfortunately said in another part of my book that it is "most difficult to conjecture by what transitions such organs could ever have arrived at their present state." Yes, it may be unfortunate, but I have contradicted myself so often that I now do not mind at all about it. Conjecture has so much befriended me that it must stand me in stead once more here; for "nothing can be more hopeless than to attempt to explain this similarity of pattern in members of the same class by natural selection and the struggle for life."

You may say that if even conjecture can do nothing here, it must be hopeless to look for certainty. So be it. I must follow my own method. If I am satisfied, that is enough.

I believe that we are clearly of the same descent with animals of the various kinds, as proved by the number of our vertebræ. I believe, 
also, that we are clearly of the same descent as birds, because of our similitude to them in our imperfect condition before birth. Birds, I admit, have not the same number of vertebræ that we have, but if you think that I shall allow that this overturns my argument, you are very much mistaken. You may call it a "meddle and muddle" if you like. I do not. I have spoken.

I believe that all organised beings have been produced by empirical efforts at the cost of myriads of imperfect experiments, though "on the theory of Creation" there is every appearance of One Mind, master of the whole work, foreseeing the end from the beginning, holding all forms of life in view, having them all, as it were, in its hand, and all carried out on one plan.

I believe that natural selection has made any animal perfect only after "exterminating" enormous numbers of experimental ones; failures in fact, like Beau Brummell's neck-ties, so that the world has been one vast shambles of incalculable slaughter for an inconceivable period of time. It is true that the remains of not one individual of all these failures has ever been found, but I have only to say that they ought to be, for there must have been mountains upon mountains of them, "Pelion upon Ossa" (ay, ossa, bones indeed), over and over again, to build my theory on.

I believe that " natural selection results from the struggle for existence," or in plainer English, is the Result of Destruction; yes, every part of every animal, the wing of the bat, and the hand of the ape, is so. The whole of Nature is one great battle-field, in which every living creature, and every part of each, has only been produced by the murder of its ancestors, time out of mind, and could only have "survived" by the "extermination" of every competitor in hecatombs, so that its own life is, after all, only a triumphant blunder.

I believe that the bones in the arm of the monkey, the wing of the bat, the fore leg of the horse, and the flipper of the seal, are not of any "special use to those animals," but are only due to "inheritance." You may call this solemn trifling, and may ask how these animals would do without them? That is their affair, not mine. It follows, indeed, that a better architect would have given these animals more useful limbs, and that the works of Nature might be vastly improved upon-in my opinion,-though I see that, even as it is, a horse can gallop a mile iu a minute, a monkey can climb from bough to bough in a most surprising manner, and a seal glide through the water in a marvellous way, the similarity of its structure to that of those others being no manner of hindrance to it. You may, indeed, reply that if the bones of the fore arm of the ape were of no use to the ape they cannot be to us its descendants. You may call this logic, but I have no place for such an argument in my book.

I may "believe" that the ancestor of the seal had not a flipper, but a foot with five toes ; and I may "further venture to believe" that the several bones in the limbs of the monkey, the horse, and the bat, were of more use to their common ancestor than they are to themselves.

I believe, I cannot deny, that you would be justified in saying that if the ancestor of the seal had five toes, it may have been either a man or an ape, or more probably, perhaps, a bear, which, as I have elsewhere stated, had a natural tendency to become "very like a whale." All you see is fish that comes to my net, as I said before.

I believe, yes I believe, that on my theory, among the "swarms" of creatures "totally unlike any existing animal," it is highly probable that the ancestor of the seal with five toes "may" have played his pranks. 
I believe that my own ancestor's legs and arms, in that form, were of more special use to him than they are to me, but that Nature has done the best she could for me with those limbs under existing circumstances.

I believe, accordingly, that the machinery of our bodies has been deteriorating as to practical use; and as to their being of special use to us, they have rather retrograded as to that, so far as we are concerned. I grant you that we are, that we must be, improved upon apes, but, nevertheless, have deteriorated in our limbs from their and our unknown ancestors, whose history is lost in the mists of antiquity. All this rather involves a contradiction, I own, but I cannot help it. I must stand by my theory.

I believe, indeed, that on my theory this "Great Unknown" having limbs of such special use to him ought to have come off conqueror in the "struggle for existence," but it seeems to have been all the other way, and the favoured animal was "exterminated" and the inferior perpetuated, so that instead of the chef d'curre, we have nothing but bats, seals, donkeys, apes, and men!

I believe that the "indefinite repetition" of the same part or organ is the common characteristic of all "low or little-modified forms," and therefore we may readily conclude that the unknown progenitor of the vertebrata "possessed many vertebræ." It militates rather against this dictum that the said ancient Incognito had limbs of more use to him than are those of his descendants, the horse, seal, bat, and monkey, are to them, and yet that he was a "low and little-modified form." But $N^{\prime}$ importe; if my theory cannot put up with such contradictions, what is it good for?

I believe that Nature does nothing "by leaps," and that every separate part of every animal is the result of natural selection in the inconceivably vast allowance of time I ask for my theory, and although this also flatly contradicts my statement that the ancestor of the vertebrata put in an appearance with many vertebræ ready made, I cannot give up the back-bone of my argument.

I believe, I say, that the ancestor of the vertebrata had a great many vertebræ to begin with; he must have been the first, and could therefore have had no vertebrated animal before him; or, in other words, if you like it better, was created, for I do hold with the doctrine of spontaneous gencration. You may ask me whether it may not have been in like manner that the ancestor of the birds had feathers, he of the fishes had scales, and so on. Yes, you may ask me if you like.

I believe that the fore and hind legs of the vertebrata and articulate classes are homologous, but the middle legs of insects are not so. They, therefore, have no business where they are, but are mere interlopers. As such, I have nothing to do with them.

I believe that the bear, "with his mouth open to catch flies," as I have said, was the immediate ancestor of the whale. Yet the bear has hind feet very useful to him, but the whale, though it has fins or paddles in the place of hands, is absolutely without even the analogues of the hinder limbs. How is this? you ask me. I don't know.

I believe, of course, that the bat was not so created at first, but was "worked out" of some other form in the usual way. It had at first a body without wings, small or large, just as bats are now, or wings without a body, I am not quite sure which.

I-believe that they were formed to live on insects, but how they managed to catch them it is not for me to say. I suppose they did the best they could. They only can live from foot to mouth now, so that they must have been much worse off then. But by degrees their 
fore hands began to lengthen, and then their wings. As they lost their fore feet, and before they got their wings, they must have been in rather a bad way, for it is clear they could neither run nor fly. Myriads of them must have succumbed to the process in the untold ages I have to beg, but those that somehow or other lived on in the quarter or half-state, and all the intermediate stages, "exterminated" all competitors. This is my natural history of the bat, first edition.

I believe that the like to this is the natural history of every other species of living creature, mututis mutandis. You may say that it is really too ridiculous. It is not so to $\mathrm{my}$ mind. No doubt the animals in transition must have perished, being neither one thing nor the other, and of course those which had no beneficial change must have perished also for want of it. This I must own has rather a queer look about it, and "if it had been asked how an insectivorous quadruped could possibly have been converted into a flying bat, the question would have been far more difficult, and I could have given no answer;" yet I think "such difficulties have little weight."

I believe that dogs preying on hares and rabbits, the rabbits became scarce and the hares increased. Then the dogs would try to catch more hares, and the dogs "with slightly plastic limbs" (for which I beg the whole question) would be "slightly favoured," and so would live longer and survive through a scarcity of food, and would also have more young with a tendency to inherit their advantages. Yes, "I see no reason to doubt that these causes would in a thousand generations produce a marked effect, and adapt the form of the dog to catching hares." You may quote Professor Owen that "this condition of things, if followed out to its full consequences, seems only to tend to my original inference, viz., an extinction of species, for when the hares were all destroyed the long-legged dogs would perish; at most there could be but a reversion to the first form and condition." Professor Owen may argue in this way if he likes. He and I differ, that is all. As to the short-legged dogs and what would become of them in one generation, not to say in a thousand, all I have to say is, "Love me, love my dog-ma."

I believe, as to birds, that it took untold ages to make the first bird out of I know not what. The process began at first somewhere or other, though I know not where. One new form succeeded another in untold profusion for a few hundred millions of ages more or less, each form becoming more and more like a true bird, till at length, after the slaughter of more than as many hundreds of millions of them, a bonâ fide cock and hen were hatched, the product of the extermination of innumerable ancestors. "Further this deponent sayeth not," except that I cannot tell you of what so-called species it was-may be an eagle or may be a dove. I rather incline to think that it must have been the latter, as it would be somewhat awkward for a bird of prey to come into being and to find n', prey for it to prey on. At all events the "new and peculiar line of life" was secured.

I believe that after this, "many divergent forms spread rapidly." It is indeed true that I have before now laid it down, and that over and over again, that " natural selection always acts very slowly," but if I cannot say a little of anything where should I be? I tell you that when once my first bird came out, I cannot say whether " $a b$ ovo" or not, all the tens of thousands of species there are now soon began to fly about. Such were their "plastic tendencies." How pretty !

I believe that all this "believing" is a most excellent substitute for proof. Hodge's razors were made to "sell," not to "cut," and I think his a very good example to follow. No doubt in the process of birdmaking many unusual forms were totally lost, and that by myriads on 
myriads, to say nothing of the failure of countless experiments wasted in the endeavour to connect the different orders, genera, and species. The "struggle for life" you see was too much for them, though not for me, and so it came to pass that there is such a vast liatus between birds and the vertebrated animals, as also the separation between all the families of birds themselves.

I believe that Cuvier only showed his ignorance-in comparison with me-when he laid it down as to "every organised being" that all their parts "correspond," and that "none of these parts can change without the whole changing." Such a dictum 1 have sense enough to see must be fatal to my whole theors. Ergo, he must be wrong, and I must be right. I cannot for a moment allow that any single created being is perfect; I can only suggest ideal improvements in every one of them, "beueficial changes in a slight degree," and so on, and on, and on.

I believe that all the correspondence in any creatures between their organisation and instincts are purely accidental, and must be so. All are explained by the "sequence of events" as ascertained by me.

I believe that a spider had at first no capacity for catching insects, and that the instinct by which it makes its web was not given to it for that purpose ; that carnivorous animals were not designed to keep down others, that birds were not made for living in trees, nor fishes in the sea, nor insects to act the various parts they do, and that the plants of the earth were not created for food for man or animals. No; all these things are the results of blind chance acting at random through incalculable ages of failures, the present end being at last hit upon, all the predecessors of existing creatures having been "exterminated" in the process. Design had nothing to do with the results; they are all cisme of the "sequence of events." Very good of them, was it not?

I believe that none of the beauties of Creation were intended to please the eye, or any other sense. "This doctrine, if true, would, no doubt, be absolutely fatal to my theory:" neither the colours of flowers, nor their scents, nor the varied plumage of birds nor their songs. No; they are all accidents. You must take them as you find them, and believe me that they are all the results of the "sequence of events," or the "chapter of accidents," and not of any studied plan.

I believe that the beauty of the male birds is to be attributed to the coquetry of the females, beyirning with their admiration of some eccentric feather till the whole plumage followed suit, "fine by degrees" and "beautifully more." You may call this a miserable puerility. So be it. I hold it to be equal to the wisdom of Solomon, or if my modesty will allow me to tell the whole truth, vastly superior to it.

I believe, "I see no good reason to doubt," that female birds by selecting, during thousands of generations, the most melodious or beautiful males, according to their standard of beauty, might produce a marked efiect." You say, how much obliged to the hen birds we ought to be for the production of all the beautifully plumed forms of birds we see, foreign and British, and all their variety of songs. Yes, I think so too. You are right for once.

I believe that changes in the structure of animals, which imply and involve an intuitive knowledge of the profoundest secrets of Physiology, are effected in all creatures, while yet, as in the case of a toad or an oyster there is no intellect at all exercised in the transmutation, nor any definite plan or object in view as to what is to be attained to. Yes ; thus from utter imbecility and the most profound ignorance, the highest wisdom and the greatest perfection of strength are evolved by evolution Only give helplessness, ignorance, and nothingness time enough, and they will conjuse you up anything I please. "I am monarch of all I survey 
is the motto of my theory, like crusoe's fable of old. Wisdom and power have had nothing to do with the "wonderful works" of Nature. Ex nihilo they all have come. All is the result of innumerable millions of blunders. It is they that have filled the world with what you call the wonders and beauties of Creation.

I believe that natural selection is infinitely better adapted to the more complex "conditions of life," and "of far higher workmanship" than any thing man can produce; and by " natural selection" I mean the "sequence of events." Thus, you see, events are workers, and causes are produced by results. This, even common sense will at once tell you.

I believe that though Professor Phillips has said that the human mind could not, even with the materials, have predicted the complete arrangements we find in such adaptations as the various kinds of tails in the falcons and the swallows, the woodpeckers and the divers, yet that a monad could have a capability for the development of all such in the "sequence of events." I hold it to be so, that is sufficient for me. Let it suffice, I repeat, for you.

I believe that for the formation of the most complex form, it is not necessary to know how to make it. That being so, because 1 say it, there could not be supposed to be any All-Wise CREATOR.-Q.E.D.

I believe that by natural selection pairs of creatures appeared at the same time suited to each other (and to my theory). How kind of them

I believe that it must have been so, because my theory would break down if it were to be supposed that in any number of millions of ages only one individual elaborated a tail, or a wing, as the case may be. No; there must have been two worked out for each other "just in the nick of time," as the saying is.

I believe that natural selection is the Great CREATOR. And why not? Ipse dixi. How do you get over that?

I believe that there was no intelligence presiding over the plan of Nature. Cuvier, indeed, says that there was, but what do I care for Cuvier?

I believe in many "beautiful contrivances," though I do not believe in any contriver. It suits me to do so, and that is all I have to say.

I believe that the "struggle for life," which I have fancied, must have "exterminated" millions upon millions of luckless failures. - I may be a mere assumption on my part, but 1 deal in assumptions.

I believe that no explanation is at all necessary of my taking it for granted that before the eye in its present state was formed there must have been a "single rudimentary eye," able, but only able to discern "light from darkness, but nothing else." How the first animal came to have it, is not for me to say. It had it, I say. I cannot tell you how natural selection made it, or made it to discern light from darkness. All I can say, is, that. "he who will go thus far, ought not to hesitate to go farther." (True enough!) "His reason ought to conquer his imagination" (for all that Tyndall says about the "use of imagination in science") " in extending the principle of natural selection to such startling lengths." That is my opinion, and opinion, mine at least, is everything.

I believe that I can give you a receipt like Mrs. Glass's one for making an eye- "Take a thick layer of transparent tissue," and so on. You may ask me how the materials came to be at hand, and so readily You may call this a pertinent question. I call it a very impertinent one. I don't like it at all. It does not suit me. I altogether therefore gnore it. 
I believe, to proceed, "I see no very great difficulty in believing" that " natural selection" has worked out an eye of some 24,000 lenses, as in an insect, from my supposed original "optic nerve, merely coated with pigment." Aladdin's Lamp was nothing to my natural selection !

I believe that only let this "process go on for millions on millions of jears, and during each year on millions of individuals of many kinds, and may we not suppose that a living optical instrument might thus be formed, as supcrior to one of glass as the works of the Creator are to those of man." You say its all "suppose and suppose," as the old Scotch ballad says. Well, suppose it is-what then?

I believe that "thick layers of tissue" were manipulated, in some way or other, to produce that result; but as I was not there to see the process going on, it is very unreasonable of you ts expect me to tell you all or anything about it.

I believe that it all came of a "nerve sensitive to light;" but how there came to be such a nerve is a question you need not ask me. Whatever was, was. That is a self-evident proposition, and proves my case.

I believe that there was no design to produce such an eye, but only that there happened to be a " nerve sensitive to light" just where it ought to be in the head, and at the same time "spaces filled with fluid," all to hand-in fact, "this, that, and the other," and a "power intently watching the process," natural selection to wit-but all accidental, nothing of purpose. You may say that you have a right to be indignant at such an insult offered to your common sense. You may be; but I have nothing to do with common sense.

I believe that natural selection was thus "intently watching each accidental alteration," but without any prescribed plan of her own. It was altogether a fortuitous proceeding. Thus, you see, the eye was the result of a series of accidents, going on in millions upon millions of billions upon billions of years, and at a sacrifice of a still greater number of lives in failures. This is a philosophical argument; and as it is quite sufficient for me, let it suffice for you also. In a word, only take for granted all my "vain imaginations," and "we may believe that a living optical instrument was thus formed, as superior (as I said) to one of glass as the works of the Creator are to those of man." By "Creator,"you will of course understand that I mean a Creator of my own creating that is to say, in other words, "natural selestion."

I believe, you see, that in order to make a perfect animal or creature of any kind, it is not necessary at all to know how to make it. Not in the least-certainly not. The only three postulates that I claim are, Accident, Ignorance, and Extermination. By these three acting together, all that is called Creation came into being as we see it.

I believe, for I cannot deny, that one of the Trilobite family, the Asaphus Tyrannus, has no fewer than 6,600 facets to each of its eyes, and Buckland states that it was "created in the fulness of perfection," or to use my own words, "as perfect as possessed by any of the articulate class." I have, no doubt, contended that it takes millions upon millions of ages, each million with millions upon millions of failures, to make anything like an eye at all; yet, as here we find a perfect eye in the Trilobite, whose fossil remains are found in the most ancient of all the formations, and which, therefore, in the words of Ansted, must have been among " the earliest of ereated beings," this fact, I say, staring me in the face, I "see no difficulty" whatever in it, by simply "imagining" that it must have been gradually coming to that state of perfection in billions upon billions of ages before the beginning. You understand, do you not? Nothing can be more plain or simple. It merely is an instance of the "use of the imagination in science," Tyndall's grand discovery of which 
is the greatest fact in modern philosophy. You may say, if you please, that it is all fiction, and so on. Leave that to me; I know better.

I believe that if " humble bees were to become rare in any country," it "might be a great advantage to red clover" to have a shorter flower, so that the " hive bee should visit its flowers." "Thus I can understand how a flower and a bee might slowly become, either simultaneously, or one after another, modified and adapted in the most perfect manner to each other." This, you see, would be of mutual advantage to both of them, the bee getting honey and the clover fertility; but, of course, this could only be after the destruction of millions of races of bees and ditto ditto of clover till they became suited to each other. You may exclaim with Dominie Sampson, Prodigious! Prodigious!! Prodigious!!! Well, perhaps it is. You may add, too, if you like, that it must be exceedingly kind of the bees, as they have done from the first without the red clover, to self-sacrifice themselves as such in untold millions for what they can do so well without. It no doubt is so, but I have always found bees very obliging to all my demands upon them. I may say that I feel particularly obliged to the queen bee, who, though she does not "gather honey every day from every opening flower" herself, resolved to lay eggs which should produce bees so well-behaved towards the red clover.

I believe that this notion is to "banish the belief of the creation of new organic beings, or of any great and sudden modification of their structure." Such notions serve the purpose of Infidels till they are exploded. Professor Phillips has, indeed, said that "No one who advanced so far in philosophy as to have thought of one thing in relation to another will ever be satisfied with laws which had no author, works which had no maker, and co-ordination which had no designer." That was his opininn, no doubt; mine is different. Fiction before fact, any day, for me.

I believe that "there is no such thing as species," and I also believe that "all varieties are in the act of becoming species." What next? you will ask me. Whatever I please, is my answer.

I believe that natural selection will, some time or other, cease from her carnage of extermination, after the slaughter of infinite millions beyond all power of calculation, or even of thought; and that every plant and every animal will be perfect. Whether they are to feed on one another or not, I leave to them to say-what care I? There may be men with wings for aught I know, or sirens and satyrs, mermaids and dragons, centaurs and sphinxes, animals able to talk, and so forth in the "sequence of events." The understanding is all very well in its way, but commend me to the "use of the imagination," as aforesaid. Nothing like it in science! Has not Tyndall said so? Of course, he has.

I believe that all this is to be brought about without any designer and without any plan. What are a few impossibilities, more or less, in the way of such a grand idea?

I believe that the intellect in man has proceeded from that which had no intellect, all by natural selection. You may ask me who selected natural selection. Ay, "there's the rub," as I have said before. I am not going to tell you, so you need not ask me. It is easy enough to ask a question, but not always so easy to answer it.

I believe that the first creature did, in my own words, "flash into existence," somehow or other. You may call this an act of Creation, I do not. I have, indeed, put the question "Were the numerous kinds of animals created as eggs, or seeds, or full grown"? What I mean, so far as I know my own meaning, is, that as whatever is, is, so whatever was, was. Intelligis-ne? 
I believe that this was the "simple beginning" of all things. You may call it a miraculous act of a Creator, but I hold that it was nothing at all of the sort. It was a Creation, but there was no Creator. It may be quite unreasonable, but that is no affair of mine. What is a hobby good for if I cannot ride it over a fence like this, especially when mounted on such a one as Huxley's "little hor se," which he has found out for me-ready saddled and bridled, perhaps, I hear you say. You are mistaken again, I can ride quite well without either.

I believe that the only creation, if I must use the word, was that of the first organic form-

That every plant and animal has since acquired its present shape by minute accidental changes, one after another;

That these changes were useful, though without any intention that they should be so ;

That in the "struggle for life" those thus formed survived, and that those not thus favoured were "exterminated ;"

That no plant or animal became, what we now see it to be, by design, but by pure accident, favoured as just stated;

That every plant and animal is still "struggling" to keep its place, if it can, in Nature.

You probably will here ask me, whence principles of virtue or morality came to men? For if man was intended to have any sense of virtue, he must have been created for it by some antecedent. Well; but there was none such, and therefore it is all the result of the "sequence of events," just like all the rest of all the changes that have come to the various animals. It follows, therefore, on my theory, that virtuous men must have "exterminated" all who were not so lucky as to be virtuous. About this there can be no manner of doubt.

I believe that all such creatures have universally tended to rise in the scale of beings. You may indeed say, if so, how is it that such vast multitudes of the lowest forms of all still exist? Perhaps you think this is fatal to my theory. It is not-that is all $I$ have to say on the subject. Don't tell me it is a figment of my own brain. Even suppose it was, it would be none the worse for that.

I believe, though it flatly contradicts my belief, that it was not necessary for all the lower forms to be advanced, for "what advantage" would it be to the lowest forms to be advanced? Very true, you say; and you tell me to use the same argument in the case of my bears, ostriches, logger-headed ducks, and all the rest of them. How, you say, can we tell that it would be an advantage to any of them to be changed? That is a captious question, and you need not expect any answer to it from me.

I believe, have I not told you before, that all animals have been changed by some accidental benefits; but if you ask me to point to any existing animal, and say how it could be benefited by some change, that is quite another question, and one with which I do not consider I have anything to do. You tell me that it would be no advantage to a swallow to be changed into a snail, nor to an antelope to be transmuted into a frog. Perhaps not, but tell me what you like; I tell you what I have just told you.

I believe, for I have said it, that many a one of even the lowest animals in the scale, has a "really wondrous and beautiful organisation," and you may say, that if so, you do not see how it can be improved. Say so.

I believe, I repeat again and again, "How do we know that it would be any advantage for the lower forms to be more highly organised?" You say you agree with me. Of course you do; everybody must agree with 
me. Plainly it would be a great advantage, as you say, for an oyster to be changed into an alderman, for then he could not be eaten by him. No doubt about it. For myself I can swallow anything. Even such a palpable contradiction as all this goes down with me. No one can contradict me so well as I do myself, and there, you see, I have the advantage of you.

I believe, for all I have just said, that "each creature will tend to become more and more improved in relation to its condition in life." Yes; and yet you say that this is to blow hot and cold, for that the lower forms have not been "exterminated" by the improved ones, but that both live close together in innumerable forms without the slightest tendency to any such imaginary improvement-the horse and the ass for instance. Ay, the ass. How is this, you say. Yes, how is it?

I believe, this is my reply, that we must "see no difficulty in believing "-anything in fact. My argument, in short, is this: if my theory be true, it must be so; but my theory is true, therefore it is so. Professor Sedgwick has, indeed, said that if a theory proves no law, it is "worse than notbing," "it is nothing better than imposture." Professor Sedgwick was a weak-minded man, if he said so. I hold the opposite doctrine.

I believe that " assuredly if this (my) theory be true," an "in comiably great" number of links must have existed "between all living and extinct species." You say there is no trace of them, and you ask, where are they? Echo answers, "Where?"

I believe that every animal, bird, plant, \&c., are one and all striving and "struggling" with and against each other "for existence," and that natural selection is looking on with fell pleasure at the destruction of all the weakest which must go to the wall. You say, but do you not see, year after year, the same beautiful flowers as before, primroses, violets, cowslips, and bluebells? Do you not hear the same sweet notes of the birds, and do you not see them build the same wonderfullyconstructed nests that they did of yore? Do you not listen to the cry of the cuckoo as ever of old, and note the instincts of the various animals? My reply to all such questions is stereotyped, and therefore can never change, "All organic beings are striving to seize on each place in the economy of Nature."

I believe it, though I see the smaller and the smallest birds maintain their numbers as of yore-the wren and the robin, the thrush and the blackbird, the swallow and the dove, and so on through all Creation. So let it be. I have no objection, but what I say I say; and what I say is, natural selection is the be-all and end-all for me. It works by accidental change and "extermination." Every creature that does not change must be expunged from the page of Nature. You may ask me if the "origin of species" is "by means of natural selection," where it is that natural selection exists? You may further ask me, as I speak of "favoured races," whom or by what it is they are favoured. In reply, I can believe that any effect may be produced without an existent cause.

I believe in assumption without proof as the highest philosophy; in speculation not borne out by facts, and, in a word, in "imagination in science."

I believe that Locke lays it down that want of proof is one of the "causes of error," but what of that?

I believe, in fine, that "new forms" are continually being produced. You ask me to say, where? That I do not mean to do. All I can say is that unlimited time "might" have produced such-ergo, it has been so. There must have been such unlimited time, as begged by my theory, and consequently my case is proved. 
I believe, for I have confessed it, that my theory is based on imagination, not on proved fact. I have no faith in inductive reascning, as I think you will allow I have shown all along.

I believe that there is no Supreme Governour of the Universe, though Laplace has shown by the calculation of probabilities that it is four millions to a unit that the motions of the planets have been directed by a "First Great Cause," and nearly two millions to one that there was such, rather than that the sun will rise at a given moment of any given day. I have spoken.

I believe, because Huxley says so, that the Pyramids were built on the mud of the Nile deposited at a very slow rate, the fact being that it is deposited in enormous quantities in a short space of time.

I believe that the horse was tamed 19337 years B.c., though history relates that it was not introduced into Egypt till the era of the Shepherd Kings.

I believe that religion is a novelty, though in the "Book of the Dead," perhaps the oldest book in the world, the future life is clearly spoken of as well as the doctrine of a future state of rewards and punishments.

I believe what I have just said, although the Sphinx, "the father of terror," is found to have belonged to a range of temples, looking out as it does on the vast desert around with its cold impassive face, unmoved by the wreck and ruin of the world, age after age.

I believe so, I say, although it is shown that Horus was, in those ancient days, a type of the Resurrection, as Osiris restored to life by Isis, a symbol from the sun settling down in darkness and rising up again in glory.

I believe so, although there are some most excellent precepts of morality in the Papyrus Prisse, in the Royal Library of Paris, written between 3300 and 3400 B.c.

I believe, for I cannot help it, that the proportion throughout the whole of nature, between males and females, is very wonderful, and if you ask me what natural selection has had to do with it, all I can say isExcuse me-you understand-Excuse me.

I believe that the bright colours in snakes may "perhaps" be due to the admiration of the male for the female, or of the female for the male. You may ask me what evidence I have to prove this? What is evidence good for unless it proves my theory? That is the way I answer one question by another.

I believe that the beautiful eyes in the wing of the Argus pheasant were produced by the desire of the male bird to exhibit himself to advantage before the female, and "in no other way." You may think that the oblong spots which (on my theory) gave way in the course of "billions" of years to the round ones, for this end and object, even more beautiful than the eventual rounded ones. Let the bird be the judge about that. "Tastes differ," you know.

I believe, with Lucretius, that the Queen of Beauty was thus the creative power of the world. You may consider it a gross and degrading idea, worthy only of the Heathen Poet. That I cannot help.

I believe, as I have all along said, in the "survival" of the stronger creatures, and the "extermination" of all the weaker ones. You ask me how I can reconcile this doctrine with the disappearance from the earth of the Mammoth, whose skull alone, without the tusks, which were nine feet long, weighed four hundred pounds; of the Mastodon, the mightiest animal known to have lived ; of the Megatherium, that "great beast," as Professor Sedgwick called it at the 
meeting of the British Association at York, a monster clothed in "armour plate," whose feet were a yard long; of the gigantic Dinotherium, no less than eighteen feet in length; of the Iguonodon, seventy feet on end; of the Icthyosaurus, with jaws six feet in length and containing a hundred and eighty teeth ; of the Plesiosaurus, of enormous size, with the head of a lizard, the teeth of a crocodile, the body of a serpent, the ribs of a chameleon, and the paddles of a whale? You ask me also, whether this last-named came by "natural selection" from a fish, a reptile, or a beast, or from all three at once? I say that it came from something, or that something came from it. Which way it was, I leave you to find out for yourself, if you can.

I believe also, as to birds, in the "survival" of the strougest, though the marks of the footsteps and egg of a bird have been found which must have been twice as large as an ostrich.

I believe the same as to flying reptiles, though I have before me the fossil remains of the Pterodoctyle, an enormous vampire, with a long snout like a crocodile, and which was able either to swim, fly, or creep, or to hang by its claws from trees.

You tell me that Buckland said that all these "point out unity of purpose and deliberate design in some intelligent First Cause, from which they were all derived." I think no more of Buckland than I do of Cuvier, or Sedgwick, or any other such. How could either of them be Darwin? I should like to know. Who cares for the opinion of any of them, or of all of them? I do not, for one, not I!

I believe, as I have told you again and again, that the imagination is of far more use in science than reason. You tell me that Milton has said, "Our Reason is our Law." He said so, did he? Perhaps he did, but pray do not name Milton's opinion in the same day with mine. That would be rather too much.

I believe that the world has lasted for long enough in pre-historic times, and man upon it in all so-called Time of inconceivable duration. You may possibly ask me how it is that if so it has not been filled and overfilled with mankind ages before this? That is a question I cannot answer, at least I decline to answer it. I consider it as quite beneath me to notice it.

I believe that "one hand has surely worked through the Universe," though I have also said, over and over again, that there has been no such hand at work at all. You may call this a palpable contradiction. Let it be.

I believe that the old-fashioned notion that humility is the unfailing characteristic of a man of science is quite exploded, and that conceit and self-opiniation have properly taken its place. I can only speak for myself, and I am thoroughly self-satisfied. Let that content you. Mili me plaudo.

$I$ believe, to conclude, you will allow me to repeat, that if such writers as Cuvier, Sedgwick, Buckland, and others agree with me, they are in the right; if not, they are in the wrong. What more need be said? Why waste more words about it? That is the long and the short of the matter, and it settles the question.

To which I may add, what is an opinion good for, unless one stands to it? At all events I am of the "saine opinion still," evidencee or no evidence, proof or no proof, right or wrong. That is my ultimatum.

\section{The Conference is at an END.}

I will supplement the above per contra, with the opinions of The Times and other papers, which are not so flattering to the scientific attainments or reasoning powers of the Darwinites as their own estimate of themselves : 
"For this reason we must needs express our disappointment with the more important part of Mr. Darwin's Book. His discussion of the faculties of man in comparison with those of animals appears to us utterly inadequate to the subject, independently of its being insufficient to sustain his theory. As it seens to us, he has not merely failed, but he has not duly grappled with the essential difficulties of the question. He has thought it possible to leap by the aid of a few illustrations over the momentous and arduous questions respecting the mental powers of men and animals, and the moral nature of man is dissected with a most rapid and unpenetrating hand. We can only express our conviction on this point by saying that on these subjects Mr. Darwin appears quite out of his element."

"For a natural philosopher to appeal to such superficial resemblances is much the same as for an astronomer to appeal to the apprehension of the vulgar with respect to the motions of the heavenly bodies."

"But the truth is that Mr. Darwin's argument is at every point supplemented by enormous assumption. The utmost he proves, not merely in his present but in his former book, is not what has been, but what may have been, and he converts the 'may' into a 'must' by the sole force of the ever-present assumption that all forms of nature have been developed out of other forms. To our minds, the book bears in its very mode of expression, of which we have given some illustrations above, a character which is wholly unscientific. Science tells us what has been, what is, and what will be. But Mr. Darwin's argument is a continuous conjugation of the potential mood. It rings ihe changes on 'can have been,' 'might have been,' 'would have been,' until it leaps with a bound into 'must have been.' "

"When Mr. Darwin is confronted with the extremely remote and uncertain nature of the agencies on which he relies, he continually falls back on what 'might have been' in the lapse of unlimited periods of time. Such a style of argument is, to say the least, destitute of any scientific value. It is impossible to say what might or might not have been during periods so vast that we have no experience of them. For all we know, the vitality of species might wear itself out in the lapse of ages, or by some law of eyclic change, they might assume new forms. To call in aid such an indefinite agency is a mere veil for ignorance. It may even be doubted whether to assert that a process takes effect in an infinite time. be not simply a roundabout way of," etc. etc

"If in short, in its general application. Mr. Darwin's hypothesis is utterly unsupported by observed facts, it is still more destitute of such support in its application to man."

"This is precisely the solution which Mr. Darwin is unable to apply to his instances of approximation between species. If he could say in a single instance, 'solvitur ambulando,' 'here is a case of one true species having passed into another,' we should have a practical proof that the kind of approximation he brings to light is of such a kind as to end in coincidence. But this, as we have seen, is what he has not done. It is, in fact, not a little curious that the finite time which Newton demands is the very condition most energetically repudiated by Mr. Darwin and his followers. They place no limit whatever to the amount of time whicls their process requires. The knowledge of so prolonged a proof, would have been of no practical avail even to Methuselah."

"We are reminded, in fact, by such speculations, of the famous story which Corporal Trim endeavoured so effectually to recite to Uncle Toby. ' There was a certain king of Bohemia,' said Trim; 'but in whose reign except his own, I am not able to inform your honour.' Uncle Toby was more accommodating than we are able to be from a scientific point of view. But we recommend the gracious permission he accorded to the corporal as 
a most appropriate motto for speculations of this kind. 'Leave out the date entirely, Trim,' said my Uncle Toby. In almost similar language, 'there was a certain Monkey,' says Mr. Darwin; of that he is quite sure, and he frequently reiterates the assurance; "There was a certain Monkey; but in what period or country, except his own, I am not able to inform my readers.' The certainty, unfortunately, is hypothetical, and the particular monkey unknown."

"We are at a loss to understand the value of all this complieated guess-work. It represents a kind of Ptolemaic theory of creation heaping supposition on supposition and multiplying cycles of action as each supposition requires to be supplemented. It is the most conspicuous example yet afforded of that 'use of the imagination in science," on which professor Tyndall dilated with such unscientific enthusiasm last Autumn. Mr. Darwin's imagination is inexhanstible, and his power in this respect contributes greatly to the charm of his strictly philosophical writings, but he does not hesitate, in accordance with Professor Tyndall's advice, to let it take the place of science when the means and methods of science fail."

"In section D (Anthropological Department) the meeting was held in the great lecture theatre of the museum, so as to accommodate the large number of persons who desired to attend. The question of haman relationship to the ape was again talked about (for it cannot be said to have been discussed) by many speakers who vied with one another in loudness of declamation and shallowness of argument."

"This assumption is the very point to be prove $d$. To argue from it is to assume the whole doctrine of evolution. The assertion in question is scientific or not, according as it is true or not. The only scientific question is whether, as a matter of fact, species have been developed by force of circumstances out of other species, and man out of an ape. It is certainly $n$ ? scientific argument to assume that they must have been."

"Starting from the unsubstantial presumption just indicated, Mr. Darwin proceeds to speculate on the manner of man's development, without being able to adluce the slightest evidence that facts correspond with his hypothesis. The history, however ingenious, is purely imaginary from beginning to end."

"Further consideration has led him to perceive an imperfection in his hypothesis of natural selection. ' $\mathrm{He}$ had not,' he says, 'sufficiently considered the existence of many structures in animals which appear to be, as far as we can judge, neither beneficial nor injurious ;' and this he believes to be one of the greatest oversights yet detected in his work. In other words, the action of Natural Selection will not of itself sustain the theory of the continuous evolution of all organised beings from inferior forms."

"That, at all events, is the practical result for all the purposes of life. If, as seems to be admitted even by the most adarnced Evolutionists, species be so permanently fixed that millions of years would be necessary to transform them, it follows that for all human purposes they must be treated as permanently independent."

"It is impossible to maintain unbroken gravity in discussing such a dream. But let us turn to Mr. Darwin's investigation of the physical bases of his conclusion, which appears to us scarcely less unsatisfactory than his inquiry into its mental and moral bearings. He simply accumulates a variety of points of similarity between the human frame and that of animals."

"There is mucl reason to fear that loose philosophy stimulated by an irrational religion, has done not a little to weaken the force of religious principles in France, and that this is at all events one potent element in the disorganization of French Society. A man incurs a grave responsibility, who, with the authority of a well-earned reputation, advances at such a time the disintegrating speculations of this book. He ought to be capable 
of supporting them by the most conclusive evidence of facts. To put them forward on such incomplete evidence, such cursory investigation, such hypothetical arguments as we have exposed, is more than unscientific-it is reckless."

"We wish we could think that these speculations were as innocuous as they are unpractical and unscientific, but it is too probable that if unchecked they might exert a very mischievous influence. We abstain from noticing their bearings on religious thought, although it is hard to see how, on Mr. Darwin's hypothesis, it is possible to ascribe to man any other immortality or any other spiritual existence, than that possessed by the brutes. But, apart from these considerations, if such views as he advances on the nature of the moral senses were generally accepted, it seems evident that morality would lose all elements of stable authority, and the 'ever fixed marks' around which the tempests of human passion now break themselves, would cease to exert their guiding and controlling influence."

"It should be the work of science to reveal this difference, not to construct theories on its mere apparent magnituude. But Mr. Darwin urges that this homological construction of the whole frame in the members of the same class is intelligible if we admit their descent from a common progenitor, together with their subsequent adaption to diversified conditions. 'On any other view'' he says 'the similarity of pattern between the hand of a man or monkey, the foot of a horse, the flipper of a seal, the wing of a bat, etc., is utterly inexplicable.' We fail to see the inexplicability. What is there unreasonable in the supposition that they have all been formed on the same general plan? Mr. Darwin's only objection is that 'this is no scientific explanation,' but this is simply to beg the question."

"We fear the truth is that the study of mental philosophy, under the disastrous influence of one or two popular writers, has of late years become extremely loose and superficial, and Mr. Darwin does but illustrate the general vagueness of thought which prevails on such subjects."-TIMES.

Here are a few more instances of the way in which these would-be Philosophers have been set down by the London Press. The next is from the "JOHN Bull."

"There is still, it seems, some uncertainty at one stage of the evolution :

No one can at present say by what line of descent the three higher and related classes-namely, mammals, birds, and reptiles-were derived from either of the two lower vertebrate classes, namely, amphibians and fishes.-(Vol. 1., p. 213.)

"The remaining steps, however, ' are not difficult to conceive.' Possibly not, if you start as Mr. Darwin does, by assuming his principle of evolution as the sole origin of species, and rejecting separate creation as 'unscientific.' In other words, you must first grant that man is descended from a monkey, and then it is 'not difficult to conceive' the intermediate steps; but if you decline to admit this petitio principii, you are wilfully closing your eyes to what Mr. Darwin assures you is the fact. Such is the entire circle of this gentleman's logic. The book is full of interesting observations on natural history, exhibiting more or less relevancy to the argument it seeks to sustain; but the induction never advances a step without a confession of logical defectiveness. We are treated to tendencies, and probabilities, and conjectures, which derive all their force from a previous assumption of the point to be proved. Take away this, and there is hardly a proposition in the whole work which could pretend to the character of a logical conclusion.

"The gobemouches who swallow for science all that comes from scientific men were confounded to hear of this secret laboratory of imagination. The Times protested against the notion that experimental philosophers ever draw bills. But Tyndall and Darwin know better. 
"Mr. Darwin's present book is a conspicuous example of this utterly unscientific process. It begins by assuming evolution in the exact sense which Dr. Salmon justly called a scientific imagination, not a scientific fact. From a plausible conjecture that some species may be modified descendents of other species-the very most that Darwinism can logically pretend to -its author quietly infer's a universal law, and so sets himself to inquire in the present book 'whether man, like every other species, is descended from some pre-existing form!' Having by this good beginning accomplished more than half his work, he proceeds in like mannor to 'take for granted' the high antiquity assigned to man by M. Boucher de Perthes, Sir Charles Lyell, Sir John Lubbock, and others, together with Professor Huxley's 'conclusive' proof that 'man differs less from the higher apes than these do from the lower members of the same order of primates.' Now here are at least four unproved hypotheses to be accepted in the dark before the new argument can see daylight. Of the first Mr. Darwin himself confesses that 'of the older and honoured chiefs in natural science, many unfortunately are still opposed to evolution in every form.' His greatest authority only denies the independent creation of every species, though $\mathrm{Mr}$. Darwin, in quoting his words, enlarges them into an assertion that 'species -instead of "some species"-are the modified descendents of other species. From this universal proposition, the induction is at present ludicrously scanty, while the acts and reasons on the contrary side are overpowering. The battle, in short, has yet to be fought before Darwinism can make good this first step in its hypothetical Sorites. The antiquity of man is another battle ground where it has hardly set up its banners. Assuredly it can boast no victory. On the existence of man before the Tertiary period all is yet the merest conjecture, and that of so slender a structure that it may at any moment vanish away. Sir John Lubbock's theory of a savage origin is a third hypothesis more in want of proof for itself, than able to afford proof of another. Not a single fact is established which is not quite as easily reconciled with the opposite theory. Against it is the unbroken testimony of history, that while in many nations civilization has decayed and died out, in none has it sprung up and flourished without extraneous assistance. If man were originally savage, and acquired civilization by his own exertions, we ought occasionally to find him on the rise. There are savages enough within the sphere of history, and even of present observation, to give full scope for the experiment. How is it that we never see them improving themselves, till some one comes to improve them ? Why did New Zealand remain in cannibalism till visited by missionaries within our own recollection, and then spring almost at a bound to a level beyond many parts of Europe? That the New Zealander was capable of civilization is proved by the result; if it be a natural acquisition, why did he never acquire it before we found him out? On the other hand, if he received the gift from the Briton, as the Briton from the Roman, the Roman from the Greek, and the Greek from the Egyptian, we are conducted back to an original civilization from which the separated fragments fell, and to which they return again when the long lost connection is restored, as water remounts to its level when the intervening mass is pierced without. Against this invariable testimony of history the most that is offered is that all existing nations were originally barbarous; but to infer from this that all ancient races were barbarous also, is again to beg the question. Our contention is that they were not, and we have some evidence in our favour in the remains of ancient Egypt and Assyria; to assume without evidence that these were in turn preceded by an unknown period of barbarism, requires us to admit the very point to be proved. If civilization (we repeat) did spring spontaneously out of barbarism at the first, why has it never done so since? To this question there is no reply. But if the original savagery is still an improbable 
conjecture, instead of an established fact, the whole basis of Darwinism is gone.

"Mr Huxley's doctrine is in the same category of assumtion with. out proof and against evidence. He is not more logical than his fellows, because he is more peremptory and scornful. Granting that in physical structure man approximates nearer to the ape than the ape to the lowest monkey, this is no argument for either being descended from the other, till we have admitted the two previous unproved hypotheses, universal evolution, and the savage origin of man. Again, physical structure is only one element in specific classification, and in the case of man the least important. His moral and intellectual nature is emphatically his specific difference from other mammals ; and here it is easy to retort Mr Huxley's argument. The highest ape is morally and intellectually more removed from the lowest savage than the latter from the most eminent philosopher. The savage may become a philosopher, but the ape never becomes even a savage. Neither can we detect the slightest tendency to such moral or intellectual evolution. Mr. Darwin does, indeed, collect some interesting anecdotes of quasi-human reason and affections in the lower animals, but it requires an enormous exercise of 'imagination' to elevate them into anything approaching to the nature of man. Of this he seems to be aware when he asks with a ludicrous sentimentality, 'who can say what cows feel when they surround and stare intently on a dying or dead companion?' Yes, who indeed? There is nothing novel or scientific in this sort of stuff; we have heard of dreaming dogs, and reasoning elephants, and arithmetical pigs, and beavers' houses, and the wonderful instincts of bees all our lives, and the common sense of mankind, gentle and simple, has long ago repudiated their real community with the moral and intellectual nature of man. Does Mr Darwin hope to overcome the verdict by telling us that:

If men were reared under precisely the same conditions as hive-bees, there can hardly be a doubt that our unmarried females would, like the worker-bees, think it a sacred duty to kill their brothers, and mothers would strive to kill their fertile daughters, and no one would tbink of interfering.

"What would be said if any advocate of Revelation resorted to such puerile trifling? In the case supposed, the creatures would not be men, but bees, and act like other bees. But that bees ever think anything a 'sacred duty' is one of the thousand forms of begging the question artfully scattered up and down the book. Curiously enough, the best examples are found, not among the apes, from whom we ought to inherit, but among creatures so remote in physical structure as the dog, the elephant, and the bee.

"Amid all this irrelevant gossip, Mr. Durwin notices, with the feeblest attempt at refutation, the crucial arguments that man alone is capable of progressive improvement, and that man alone fashions implements for a special purpose. To the first he can only answer that in the hunting countries foxes are more wary than in districts where they are not disturbed; and, to the second, that the chimpanzee cracks nuts with a stone, and other apes build temporary platforms (as birds build nests), which 'might readily grow into a voluntary and conscious act.' Mright! But does it? And could it, unless we admit intellectual evolution, and so once more beg the question? It is astonishing how persistently this artifice is resorted to throughout. It pervades every part of the book, till, by dint of repetition and incessant assumption; often veiled in the most subtle implications, the reader is led to think a point demonstrated for which not a shadow of evidence has been presented. Of the course of things, when reason, language, and religion have been once 'acquired,' Mr. 
Darwin writes as coolly as if such 'acquisitions' were of common experience, instead of being the wildest speculation, contrary to every conviction of our nature, and never in a single instance confirmed or indicated by experiment. It is really an abuse of language to call such writing 'scientific:' to mistake the 'Arabian Nights' for history would be far more excusable.

"Such being the character of the thesis, we need not spend much time on the new hypothesis. The moment he attempts to draw any conclusion, Mr. Darwin himself is sensible of the exceeding tenuity of his premises. Showing us plainly enough what he is in quest of, he writes of what he has found either in the optative or conditional mood. In place of what $i s$, we hear of what might, could, would, or should be-of what is probable or may be easily conceived-and unhappily the probability is often in inverse ratio to the importance of the conjecture. Here again Darwinism failing to establish its point by any kind of proof, is obliged to take refuge in imagination.

"Its author, meanwhile, with as much assurance as if he had completed a mathematical demonstration, blandly apologises for the shock to our taste and our religion, by avowing that, for his own part, he would rather be descended from a monkey than a Fuegian savage: he adds that 'it is not more irreligious to explain (?) the origin of man as a distinct species from some lower form, than to explain the birth of the individual through the laws of ordinary reproduction.' The first excuse overlooks the little fact that the simian ancestry involves the savage also."

Again,

\section{"DARWINISM AND ASTRONOMY.}

"To the Editor of the Times.

"Sir,-After the many solid arguments adduced in your late admirable and most welcome notices of Mr. Charles Darwin's recent work, I should like to make only one suggestion. Mr. Darwin's theory requires us to believe that animal life existed on this globe at a period when, according to a theory much more plausible than his, the earth and all the planets with the sun constituted but one diffused nebula. Astronomers really have some data on which to found this theory of theirs, since marked variations in the conformation of several nebulæ within historic times are now on record; whereas all the variations which Mr. Darwin has been able to point out in species, and especially in man, within the same limits of time, are either zero or of an extremely nebulous character.

"I remain, Sir, yours faithfully,

"April 10."

"ASTRONOMICUS.

Thus much from the Times and John Bull, now from the Globe:

"The other point to note is Professor Huxley's speech. The learned gentleman is not only abandoning himself to a bad habit of mischievous talking; he is becoming inane. What did he mean by entertaining a company like that assembled around the board of the Royal Academy with a wretched réchauffé of the old story that man is a cooking animal with the obvious variation $a$ propos of the occasion that he is distinguished by the power to 'draw!' Professor Huxley must either be running rapidly to seed himself, or he has a very low opinion of his contemporaries when he expects them to be amused, even after dinner, with such feeble wit." 
"On Geology and Darwinism 'Dagentree' holds decided opinions. $\mathrm{He}$ regards the former as a science so completely in its infancy that to attempt to reconstruct our theology in reference to it is simply absurd :'Late researches have, I think, proved more clearly than ever it was proved before-first, that man is a very recent inhabitant of this planet; and, secondly, that man has not been produced by any process of selection or development....Darwin has left the origin of species, not where he found it, but darker than ever; for he has proved that there ought to be no species at all; and if his views were true, there could have been no such thing.' This is admirably put, and not easily answered, and the following reply to the scientists who object to the argument from design is irrefragible. 'The professor who sees in nature no traces of a Creator, will find in a wretched piece of flint, as he peers enchanted through his spectacles, the long-lost proofs of pre-Adamite man.' The truth is that neoteric science is ruined by the shallow sciolist, the lecturing professor, who, the moment a new notion strikes him, airs it to an audience of ladies at Albemarle-street or South Kensington. 'Natural selection - ' protoplasm '- 'air germs'-come into fashion and go out again like paniers and chignons."-Gs.OBE.

And lastly our friend "Punch," whose wit has always a good deal of wisdom in it.

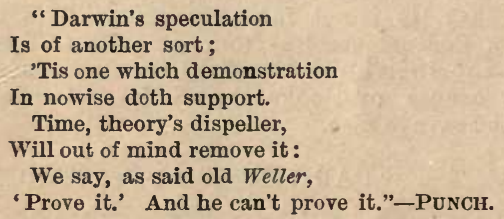

The following is Dr. Carpenter's opinion, the President of the British Association :

"There is a great deal of what I cannot but regard as fallacious and misleading philosophy- 'oppositions of science falsely so called'-abroad in the world at the present time. And I hope to satisfy you that those who set up their onn conceptions of the orderly sequence which they discern in the phenomena of nature, as fixed and determinate lans by which those phenomena not only are within all human experience, but always have been, and always must be, invariably governed, are really guilty of the intellectual arrogance they condemn in the systems of the ancients, and place themselves in diametrical antagonism to those real philosophers, by whose comprehensive grasp and penetrating insight that order has been so far disclosed."

And, another,

"It must not be supposed that there is much unity among these 'philosophers,' But in this they all agree, that they argue á posteriori, and they are all infallible."

Well wrote Canon Kingsley: "All we have to do is to wait. Nominalism, and that Sensationalism which has sprung from Nominalism, are running fast to seed. Comteism seems to me its supreme effort, after which the whirligig of time may bring round its revenges, and Realism, and we who hold the Realist creed may have our turn. Only wait-the end of that Philosophy is very near." "The tide is setting in against Darwinism." 


\section{"LOOK ON THIS PICTURE"}

WORDS OF THE WISE.

There is a path which no fowl knoweth, and which the vulture's eye hath not seen.

The lion's whelps have not trodden it, nor the fierce lion passed it

He putteth forth his hand upon the rock; He overturneth the mountains by the roots.

He cutteth out rivers among the rocks; and his eye seeth every precious thing.

$\mathrm{He}$ bindeth the floods from overflowing; and the thing that is hid bringeth lie forth to light.

But where shall wisdom be found ? and where is the place of understanding?

Man knoweth not the price thereof neither is it found in the land of the living.

"It cannot be valued with the gold of Ophir, with the precious onyx, or the sapphire."

The gold and the crystal cannot equal it; and the exchange of it shall not be for jewels of fine gold.

The Topaz of Ethiopia shall not equal it, neither shall it be valued with pure gold.

Whence then cometh wisdom? and where is the place of understanding?

Seeing it is hid from the eyes of all living, and kept close from the fowls of the air.

Destruction and death say, We have beard the fame thereof with our ears.

For $\mathrm{He}$ looketh to the ends of the earth, and seeth under the whole heaven ;

To make the weight for the winds; and $H e$ weigheth the waters by measure.

When He made a decree for the rain, and a way for the lightning and thunder.

And unto man He said, Behold, the fear of the Lord, that is wisdom ; and to depart from evil is understanding.

Canst thou by searching find out God? canst thou find out the Almighty unto perfection?

But ask now the beasts, and they shall teach thee: and the fowls of the air, and they shall tell thee.

Who knoweth not in all these that the hand of the Lord hath wrought this?

In whose hand is the soul of every living thing, and the breath of all mankind. JOB.

\section{"AND ON THAT."}

WORDS OF THE UNWISE.

" What little I know about the matter leads me to think that if M. Comte had possessed the slightest acquaintance with biological science, (Philosophers disagree, it seems) he would have turned his phraseology upside down, and have found that we can have no knowledge of the great laws of life, except that which is based upon the study of natural living beings."

"If there is one thing clear (clear!) about the progress of modern science, it is the tendency to reduce all scientific problems except those which are purely intellectual to questions of molecular physics, that is to say, to the attractions, repulsions, motions, and co-ordination of the alternate particles of matter. Social phoenomena are the result of the interaction of the complements of society, or men with one another in the surrounding universe. But in the language of physical science, which by the nature of the case is materialistic, the actions of men, so far as they are recognisable by science, are the results of molecular changes in the matter of which they are composed."

"To a certain extent indeed it may be said, that imperfect ossification of the vertebral column is of an embryonic character, but on the other hand it would be extremely incorrect to suppose that the vertebral columns of the older vertebrata are, in any sense, embryonic, in their whole structure."

"Matter and spirit are both names for the imaginary substrata of groups of natural phenomena."

"In itself it is but of little moment, whether we express the phenomena of matter in terms of spirit, or the phenomena of spirit in terms of matter."

"The extension of the province of what we call matter or causation, and the concomitant gradual banishment from all regions of human thought, of what we call spirit and spontaneity."

" Traced back to its earliest state, the matter arises as the man does, in a particle of nucleated protoplasm."

IIuxley.

Well did Sir Walter Scott declare of the Bible :-

"Within this awful volume lies

The mystery of mysteries.

Happiest they of human race,

To whom their God has given grace

To read, to fear, to hope, to pray,

To lift the latch, to force the way,

And better had they ne'er been born,

Than read to doubt, or read to scorn."

The fool hath said in his heart there is no God."-Psalm xiv. 5.

"Answer a fool according to his folly."-Proverbs xxvi. 5. 
"Which Stratn at a Gatat and Swallow a Camel."

\section{ALL THE ARTICLES}

OF

\section{THE DARWIN FAITH,}

BY

THE REV. F. O. MORRIS, B.A.,

Rector of Nunburnholme, Yorkshire,
Author of "A History of British Birds," dedicated by permission to Her Most Gracious Majesty the Queen, etc., etc.

"Ridiculum acri fortius ac melius plerumque secat res."-HoRACE.

\section{PRICE ONE SHILLING.}

"An elegant and lively jeu d'esprit. Mr. Morris has in playful but most convincing satire exposed the gross inconsistencies, the large asumptions, and the unscientific deductions contained in some well-known works. This little brochure deserves a wide circulation. It will, perhaps, accomplish mightier victories than the heavier artillery of a ponderously learned treatise."-Notes and Queries.

"A fair, though often ludicrous, exposition of the doctrines advanced by Messrs. Darwin, Huxley, and others, who claim to be philosophers, but who are by many considered and designated as philosophical atheists. The extracts from the criticisms of the London press on the vagaries of Dar. winism are not the least amusing portions of this lively pamphlet." -Bookseller.

"In a clever and amusing pamphlet, All the Artioles of the Darrin Faith, the Rev. F. O. Morris, so celebrated for his ornithological researches, exposes the many assumptions and manifest unsoundness of much of modern philosophical statement. Not all is science that comes from scientific men, and searchers after truth will do well not to accept any assertion, however positive and dogmatic, as proven, till after close and careful examination of the supposed grounds on which it rests. Mr. Morris has done excellent service by showing that many 'scientific' men, who on certain matters 'strain at a gnat,' are quite ready, nevertheless, when it falls in with their own preconceived notions, to 'swallow a camel." "-National Clurrch.

Messrs. W. H. SMrth ANd Son, 186, Strand, London, Sold at their Bookstalls, and to be had of all Booksellers. 
Dedicated by Permission to the Right Hon. LORD SELBORNE, Lord Chancellor of England.

\section{The Humanity Series of School Books, \\ FOR NATIONAL AND OTHER SCHOOLS, EDITED BY}

THE REV. F. O. MORRIS，B.A.,

Rector of Nunburnholme, Yorkshire,

Author of "A History of British Birds," Dedicated by Permission to Her Most Gracious Majesty the Queen, etc., etc., etc.

The child is father of the man."-WoRDsworTH.

Syllabus of the Series for the Six Standards.

BOOK I.-64 pages, cloth, $6 \mathrm{~d}$.

BOOK II.-96 pages, cloth, $8 d$.

BOOK III.-128 pages, cloth, 10d.
BOOK IV.-144 pages, cloth, 1s. BOOK V.-208 pages, cloth, 1s. 3 d. BOOK VI. - 272 pages, cloth, 1s. 6 d.

L O N D N :

The Society for Promoting Christian Knonledge, 67, Lineoln's Inn Fieids. The National Society, Sanctuary, Westminster, and all Booksellers.

These Books are on the List of the London School Board.

"I have carefully looked over the Humanity Series of Reading Books edited by the Rev. F. O. Morris, B.A., of Nunburnholme, and I say sincerely to such a work 'God speed.' Would that all our school books were more devoted to teaching and training the minds of the young to acts of kindness and mercy towards the brute creation. The various anecdotes, poetical pieces, narratives, \&c., are put together in such a way that while they enlist the sympathies of the children on the side of right and mercy, they are still interesting in a high degree. Every fair critique must admit them to be a valuable collection, and every Christian will wish them heartily God speed."-William W. F. KEELING, of University College, Durham, Superintending Master of a group of Schools for the Right Hon. the Baroness Burdett Coutts.

"We turn with a feeling of relief to the reading books of Mr. Morris. We wish Mr. Morris all success in this praiseworthy effort, and we hope that his books will find a welcome in all elementary schools. To teach children to love animals will not only do away with a great deal of useless suffering to the animals, but will also open a new source of happiness to the children themselves. The child will surely be a happier cbild who through long lonely days of out-door work can find ' friends in fur and feather ' all around him, and who, like St. Francis, sees a little brother or sister in every living thing that chance may bring across his path."Saturday Revien.

"Pendleton, Manchester, May 15th, 1875.

"I think they are admirably suited to inculcate kindness in children, the anecdotes being so carefully selected."-JOHN SUTTON, Inspector of Board Schools.

"WAR OFFICE, April 2nd, 1874.

"They are excellent of their kind. They ought to be introduced into every school in the country."-The REv. G. R. GLeIG, Chaplain General to the Forces. 


\section{A HISTORY OF BRITISH BIRDS,}

In Six Volumes, Super Royal 8vo, price $£ 6$ 6s., containing 365 Coloured Engravings,

BY THE REV. F. O. MORRIS, B.A.,

Dedicated by permission to Her Most Gracious Majesty the Queen.

"Mr. F. O. Morris is well known to our readers by numerous letters in which he has vindicated the right of curious birds, occasional visitors to our shores, not to be improved off the face of the earth simply because they are rare, and of birds which are not curious not to be extirpated simply because, for the time, they happen to be numerous. Lovers of Natural History and of Nature know him even better as a most diligent and agreeable writer on almost every one of the provinces in this wide subject, so far as they concern our own island. No doubt brother explorers will by no means always accept his theories or conclusions, but his premises are manifestly his own, gathered by himself, and with the refreshing air and tone of positive personal experience about them. He has carefully studied the works of other labourers in the same field, but with the view rather of ascertaining what light their researches throw on his own than of appropriating their facts.

"Numerous highly-finished plates, drawn and coloured from the birds and eggs themselves, make of these volumes, which would, if only for the letterpress, have been necessary to the student of Natural History, luxuries, though by no means dear ones, to what we are sorry to say is the far larger class of persons who like pretty books irrespective of their special subject matter. We hope some, at any rate, of such persons may be converted, in spite of themselves, into students of the world in which they have been hitherto living without taking the trouble to find out anything about their neighbours in it. Mr. Morris's Library of Natural History includes British moths and butterflies as well as birds, but we confess to a preference for our old friends, the birds. We are quite ready to accept still all the responsibility of the quotation from our columns which Mr. Morris incorporates in his preface to this second edition :-

" The proper study of mankind is man; the favourite study of mankind is certainly birds, beasts, and fishes-Natural History, in short. Above all, birds seem to exercise the greatest attraction over young and old, rich and poor." - TruEs.

"In this holiday season, when half the world is enjoying the healthful breezes of seaside and country, mountain and moor, and the other half 'in p pulous city pent ' are vainly sighing for that enjoyment, here is a book which will be as welcome to those who wander as to those who stay at home. To the former it will be a congenial guide and companion through the various pleasant scenes to which their summer rambles may lead them; to the latter it will, by its vivid delineations of Nature, almost make up for the absence of the green fields and shady woods, and blue tracts of ocean which are ever floating dimly before their minds.

"The six goodly volumes of this work, which has already gained a world-wide circle of readers, have recently appeared in a new and cheaper edition, beautifully got up, handsomely printed, and lavishly adorned with hundreds of coloured plates most admirably executed. Indeed every bird which has established itself to be styled 'British' has sat for its portrait, and been called upon to give an account of its haunts and habits, the place where it seeks its food or builds its nest, and every particular of its little history, whether it be a dweller on land or the shore, or the ' great and wide sea.' Consequently, these charming volumes carry us into all the retired green nooks, and out-of-the-way corners of old England, its quiet meadows, country lanes, immemorial woods, breezy downs (lovely meadows) and surf beaten cliffs. Wherever the voice of a bird is heard, or the wing of a bird is seen, or the shadow of a bird falls lightly on grass, or corn, or lake, or river, thither are we borne by the author in the interesting descriptions and endless anecdotes which make Morris's 
' British Birds' not only an authority in natural history, but also, what it was apparently designed to be, an eminently readable book. The sweet breath of Nature comes to us from every page. Open the volumes where we may, we are refreshed with a glimpse of uncontaminated country-

$$
\text { "Of lake or mountain, wood, or murmuring sea." }
$$

"The eye delights to rest on the coloured engravings of the birds as they pass before it in rapid and ever-varying succession. Nay, without opening the voluines, the pictures in gold, stamped on the green binding, give ample promise of the rich variety inside, and seem to invite you to look within. On one volume you see 'woodpeckers tapping the hollow beech tree ;' on another, water-ouzels preparing to dip ints the cool stream; on a third, a heron waiting silently and solemnly until a fish dimples the smooth pool; on a fourth, wild ducks floating on a reedy lake; on a fifth, guillemots resting on the edge of a cliff and meditating a plunge into the sea. Then on turning from the pictures to the letterpress you have at once a complete history of every bird that inhabits or visits this country, and a collection of anecdotes from all sources to illustrate and enliven the scientific description. Natural history is necessarily a log-book of observed facts-an aggregation of details which have come under the notice of hundreds of quick and loving eyes. One man can add comparatively little to the stock from his own observation, though every one may bring something if he has a mind willing to record the facts which his eyes have seen, and that naturalist may be said to have deserved best of the general public who presents the greatest number of these interesting facts to the common store. One recommendation of the study of Natural History in general, or of Ornithology in particular, is that the youngest beginner may have the good fortune to observe some trait, some phrase of Nature's face, which has escaped the notice of the experienced Naturalist, and to excite some such love in the minds of all his readers, young and old, seems to have been the object Mr. Morris had in view when compiling his book, which is given to the public as the result of long years of patient research and painstaking study. His idea will be manifest by a quotation of a portion of the preface to the first edition.

" My object has been, first, to collect together, as far as I could, all 'the known facts respecting the natural history of each and every British - bird, so that my work might contain a greater number of such facts than ' any previous one; secondly, to produce at the same time a readable book: 'thirdly, to give correct and life-like figures of the several species; and 'fourthly, to bring out the work at such a price as to place it within the ' reach of every class, whose taste might happily lead them to the study of - Natural History. I have endeavoured also to impart a religious character 'to this treatise on some of the most interesting works of the Creator, as 'indicated from the very first page by the motto, Gloria in excelsis Deo, ' prefixed to the account of the 'birds of the air,' and subsequently by the 'kindred one De profundis ad Dominum attached in like manner to that ' ' water birds, whose home is more or less on the 'great deep.'

"Many passages in the book might be marked to show the author's genuine love of Nature, his powers of description and illustration, and the reverential spirit with which he imbues the study of Natural History, did space allow of such quotation. It will be sufficient to say that the Rev. F. O. Morris's 'British Birds' is a book worthy of every recommendation. It will be alike an acquisition to the study and an ornament to the drawing room. It will delight both old and young. The early possession of such a work might well instil a love of Natural History into the mind of the youthful reader, and thus supply a life long interest, a never-failing resource, and an elevating pursuit, which may lead many

"'To look through Nature, up to Nature's God.'"-MonNING Post.

London : Georgl Bell and Son, York Street, Covent Garden. 


\title{
The Rights and Wrongs of Women,
}

Bx

\author{
THE REV. F. O. MORRIS, B.A.,
}

Read before the Social Science Congress at Newcastle.

PRICE 6d,

LONDON: WILLIAM POOLE, 12, PATERNOSTER ROW.

A

Double Dilemma in Darwinism,

BP

THE REV. F. O. MORRIS, B.A.,

Read before the British Association at Glasgow, 1876.

"Je vieıs de recevoir de mon excellent ami, (Sir) Bernard Burke, votre Double Dilemma in Darninisme, ; e que j'ai lu avec un vif interêt. Permettez moi de profiter de cette circonstance de rous adresser le livre que je viei.s des publier sur un sujet analogue. Il est réellement haut temps de faire justice, non pas des témérités, $m$,is des stupidités, qui se débitent ainsi sous le couvercle d'une fausse science.".- Le DR. Cox. stantr. JAMES (Ancien collaborateur de Majendie, Chevalier de la Légiom d'honneur, et des Ordres de Leopold de Belgique, de Charlcs III.d'Espagne, du Christ du Portugal, de Fiédéric du Wurtemburg, d'Adolphe de Nassau, de Saint Michael de Bavière, d'Ernest de Saxe, de Francois I. des Deux Siciles, des SS. Maurice et Lazare de Sardaigne; Membre de plusiers Académiés ou Sociétés sarantes, ctc.)

\section{PRIGE $\$ d$.}

LONDON: WILLIAM POOLE, 12, PATERYOSTER ROW. 


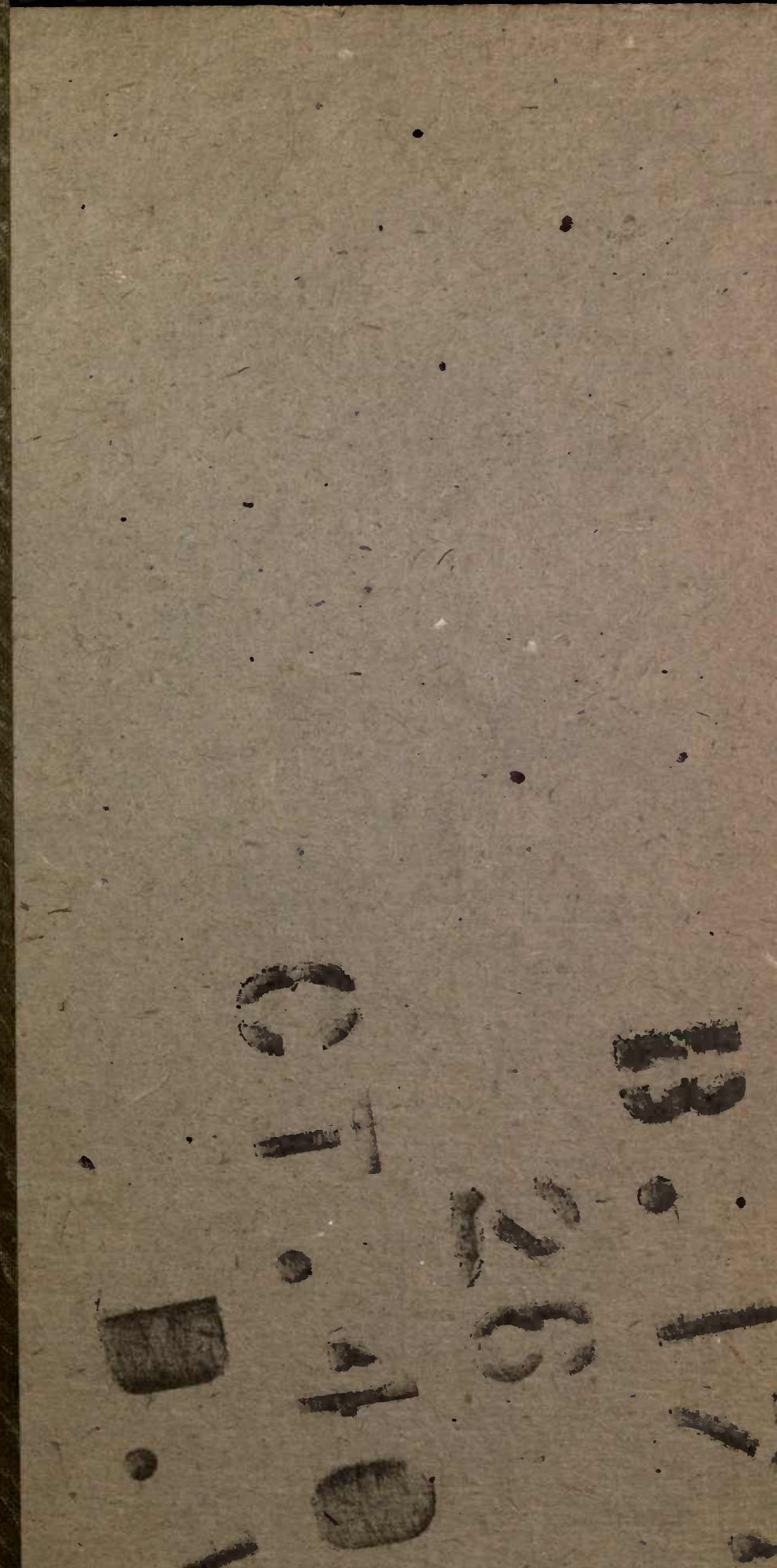


